\title{
Tectonic control on sediment accretion and subduction off south central Chile: Implications for coseismic rupture processes of the 1960 and 2010 megathrust earthquakes
}

\begin{abstract}
Eduardo Contreras-Reyes, ${ }^{1}$ Ernst R. Flueh, ${ }^{2}$ and Ingo Grevemeyer ${ }^{2}$
Received 24 April 2010; revised 19 August 2010; accepted 1 September 2010; published 29 December 2010.

[1] Based on a compilation of published and new seismic refraction and multichannel seismic reflection data along the south central Chile margin $\left(33^{\circ}-46^{\circ} \mathrm{S}\right)$, we study the processes of sediment accretion and subduction and their implications on megathrust seismicity. In terms of the frontal accretionary prism (FAP) size, the marine south central Chile fore arc can be divided in two main segments: (1) the Maule segment (south of

correlates with a thick subduction channel (Chiloé segment) that may provide enough smoothness at the subduction interface allowing long lateral earthquake rupture propagation. Citation: Contreras-Reyes, E., E. R. Flueh, and I. Grevemeyer (2010), Tectonic control on sediment accretion and subduction off south central Chile: Implications for coseismic rupture processes of the 1960 and 2010 megathrust earthquakes, Tectonics, 29, TC6018, doi:10.1029/2010TC002734.
\end{abstract} the Juan Fernández Ridge and north of the Mocha block) characterized by a relative large FAP (20-40 km wide) and (2) the Chiloé segment (south of the Mocha block and north of the Nazca-Antarctic-South America plates junction) characterized by a small FAP ( $\leq 10 \mathrm{~km}$ wide). In addition, the Maule and Chiloé segments correlate with a thin $(<1 \mathrm{~km}$ thick $)$ and thick $(\sim 1.5 \mathrm{~km}$ thick $)$ subduction channel, respectively. The Mocha block lies between $\sim 37.5^{\circ}$ and $40^{\circ} \mathrm{S}$ and is configured by the Chile trench, Mocha and Valdivia fracture zones. This region separates young (0-25 Ma) oceanic lithosphere in the south from old (30-35 Ma) oceanic lithosphere in the north, and it represents a fundamental tectonic boundary separating two different styles of sediment accretion and subduction, respectively. A process responsible for this segmentation could be related to differences in initial angles of subduction which in turn depend on the amplitude of the down-deflected oceanic lithosphere under trench sediment loading. On the other hand, a small FAP along the Chiloé segment is coincident with the rupture area of the trans-Pacific tsunamigenic 1960 earthquake $\left(M_{w}=9.5\right)$, while a relatively large FAP along the Maule segment is coincident with the rupture area of the 2010 earthquake $\left(M_{w}=\right.$ 8.8). Differences in earthquake and tsunami magnitudes between these events can be explained in terms of the FAP size along the Chiloé and Maule segments that control the location of the updip limit of the seismogenic zone. The rupture area of the 1960 event also

\footnotetext{
${ }^{1}$ Departamento de Geofísica, Facultad de Ciencias de Físicas y Matemáticas, Universidad de Chile, Santiago, Chile.

${ }^{2}$ IFM-GEOMAR, Leibniz-Institute für Meereswissenchaften an Universität Kiel, Kiel, Germany.

Copyright 2010 by the American Geophysical Union. 0278-7407/10/2010TC002734
}

\section{Introduction}

[2] The convergance rate and trench-sediment thickness exert first-order controls on the erosive or accretionary nature of convergent margins [von Huene and Scholl, 1991; Clift and Vannucchi, 2004]. At erosive margins, no sediment is frontally or basally accreted. Instead, upper-plate material is removed, resulting in a high-taper fore arc and the continental or island arc basement positioned close to the trench. Tectonic erosion is favored in regions where convergence rates exceed $>6.0 \mathrm{~cm} / \mathrm{a}$ and trench sedimentary cover is $<1 \mathrm{~km}$ [Clift and Vannucchi, 2004]. At accretionary margins, a lowtapered prism formed by imbricated thrust sheets may be as wide as a few hundred kilometers. Accretion occurs because of the transfer of material from the subducting plate to the overriding plate, either by frontal offscraping at the trench axis or by underplating at the bottom of the fore arc accretionary prism. Accretion preferentially occurs in regions of slow convergence $(<7.6 \mathrm{~cm} / \mathrm{a})$ and/or trench-sediment thickness $>1 \mathrm{~km}$ [Clift and Vannucchi, 2004]. On the other hand, von Huene and Scholl [1991] noted that even in accretionary active margins $\sim 70 \%$ of the trench sediment is likely subducted to great depths below the fore arc. The principal geophysical evidence for sediment subduction is the small width of accretionary prisms fringing most convergent margins, particularly nonaccreting margins. At these margins, the volume of the seismically imaged accretionary prism is much less than the potential volume if all sediment entering the subduction zone had been scraped off [Scholl and von Huene, 2007]. Thus, the interplay between the amount of accreted and subducted sediment plays a crucial role in the geodynamics of accretionary and nonaccretionary margins controlling the rate at which the accretionary prism grows up and the amount of sediment further subducted throughout the subduction channel.

[3] The accretionary prism grows upward either by frontal accretion or underplating against the seawardmost part of the margin's backstop. The backstop corresponds to a region within the fore arc that is significantly stronger than the region just trenchward of it. The backstop may consist of 

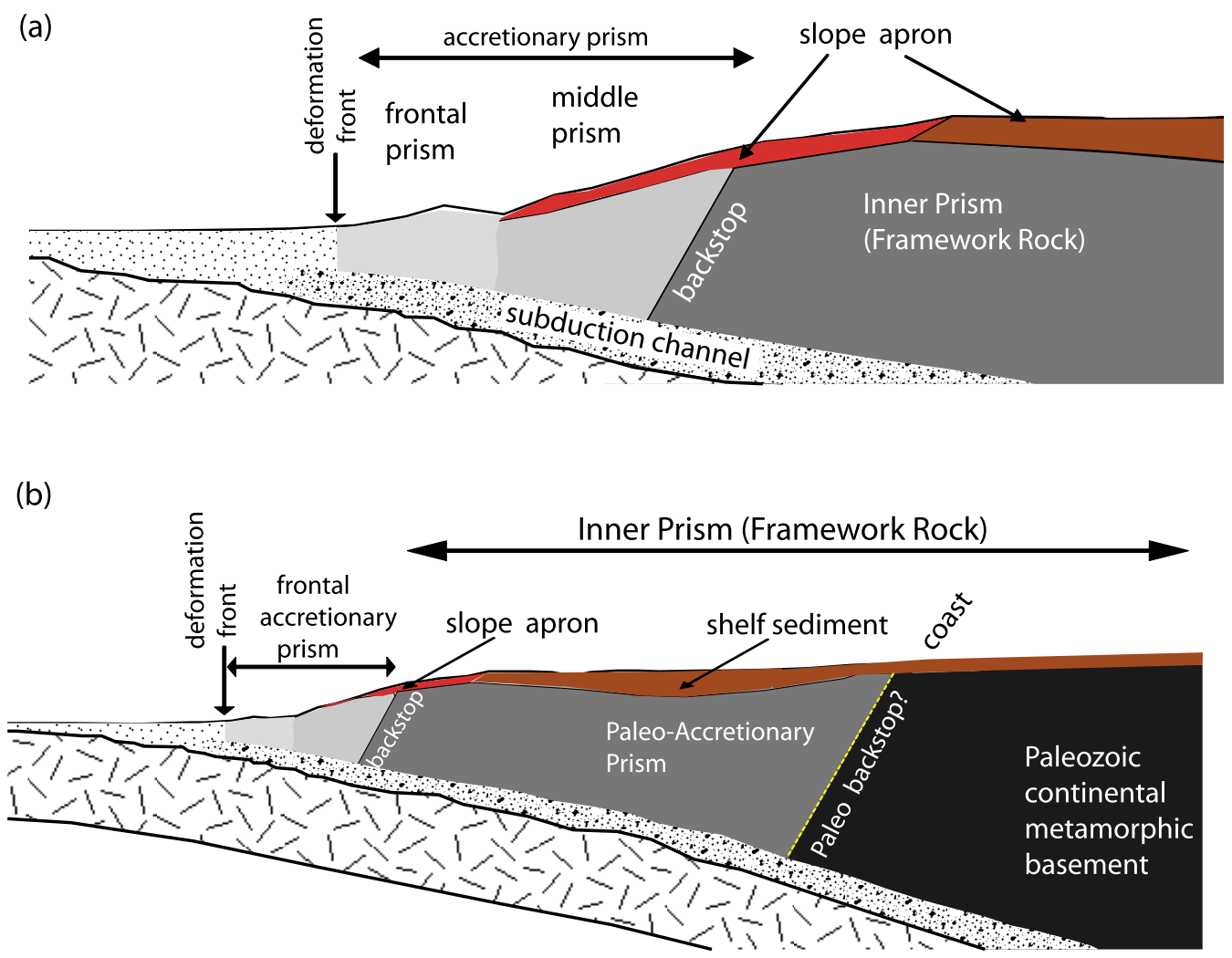

Figure 1. (a) Rock and sediment units of convergent margins. At accreting margins the rock framework (structurally the inner prism) backs a middle prism of accreted material. Frontal prisms can contain upper and/or lower plate materials [von Huene et al., 2009]. The seaward and arcward part of the accretionary prism is formed by the frontal and middle prism. The accretionary prism is limited arcward by the backstop. The inner prism (framework rock) consists of igneous or metamorphic basement and/or lithified sedimentary rock. (b) Typical scheme of the south central Chilean convergent margin. The frontal accretionary prism is typically 5 to $40 \mathrm{~km}$ wide and the middle prism is absent or poorly developed. The inner prism is likely composed by more than one rock unit. Seismic refraction [Contreras-Reyes et al., 2008; Scherwath et al., 2009] and seismological evidence [Haberland et al., 2006; Lange et al., 2007] show the presence of a paleobackstop structure that separates a paleoaccretionary prism complex from the onshore exposed Paleozoic continental metamorphic basement [Herve et al., 1988; Glodny et al., 2006].

igneous rock such as arc basement or previously accreted well-lithified sediment or any other relatively strong geological material. In general, the rocks within accretionary prisms become more compacted both with depth and with distance from the toe. The resulting gradual increase in both strength and bulk density toward the back of the prism can explain the commonly observed convexity of the upper surface of accretionary prism [von Huene et al., 2009]. Scholl and von Huene [2007] and von Huene et al. [2009] explained the conventional "accretionary prism" into three structural segments for accreting margins: (1) a frontal accretionary prism, (2) a middle accretionary prism, and (3) the inner prism (Figure 1). The frontal accretionary prism (FAP) is made of actively deforming material of accreted (lower plate) or downslope-displaced (upper plate) material. It is commonly separated by a splay fault or transitional contact from a moderately stable middle prism that in turn grades into a relatively stable inner prism of coherent margin framework (Figure 1). The middle prism (not always present and commonly referred to as an accreted prism of older material tectonically added to the margin) is presumed to contain trench sediment transferred from the frontal prism which is commonly bounded landward by a backstop of framework rock. The inner prism consists of igneous or metamorphic basement and lithified sedimentary rock (framework rock) [e.g., von Huene et al., 2009].

[4] Seismically, the backstop should correspond to a rapid landward increase of seismic velocity due to the srong contrast of rigidity and degree of compaction between the middle prism and framework rock (inner prism). Recent seismic data resolve an abrupt arcward increase of seismic velocities through the backstop region, for instance in the south central (SC) Chile subduction zone [Flueh et al., 1998; Zelt, 1999; Contreras-Reyes et al., 2008; Scherwath et al., 2009]. Detecting the location of the backstop region provides important constraints such as the size of the accretionary prism (frontal and middle prisms), and the efficiency of sediment subduction can be inferred.

[5] One excellent place to study sediment accretion and subduction is the continental margin of Chile, where there is a 
broad variability of climate and tectonic conditions from the arid Atacama Desert in the north to the glacial climate of Patagonia in the south. First-order factors controlling the tectonic segmentation of the margin and development of the outer fore arc are the character of the incoming oceanic Nazca plate and the variability in sediment supply to the trench. The latter is controlled by several factors, including glaciation periods, denudation of the Cordillera, variability of the climate, sediment transport via submarine canyons and seafloor topography [Thornburg and Kulm, 1987; Thornburg et al., 1990; Bourgois et al., 2000; Völker et al., 2006]. The most prominent feature of the incoming oceanic Nazca plate is the active Chile Rise, which is currently subducting at $\sim 46.4^{\circ} \mathrm{S}$ forming the Chile triple junction (CTJ) of the oceanic Nazca and Antarctic plates and the continental South American plate (Figure 2a). Tectonic erosion of the fore arc narrows and steepens the continental slope at the CTJ [Bourgois et al., 2000; Ranero et al., 2006] as well as the collision and postcollision zones of the Juan Fernández Ridge (JFR) with the Chile margin $\left(20^{\circ}-33^{\circ} \mathrm{S}\right)$ [von Huene et al., 1997; von Huene and Ranero, 2003]. This study focuses on the region of SC Chile $\left(33^{\circ}-45^{\circ} \mathrm{S}\right)$, situated between the tectonically erosive, empty-trench margin north of the JFR and the accretionary, trench-filled margin south of the CTJ (Figure 2). This region has been characterized using structural constrains from multichannel seismic reflection [Bangs and Cande, 1997; Díaz-Naveas, 1999; Contardo et al., 2008] and wide-angle seismic data [Flueh et al., 1998; Zelt, 1999; Contreras-Reyes et al., 2008; Scherwath et al., 2009]. A principal structure is a relative narrow FAP, 5-40 $\mathrm{km}$ wide, which abuts the truncated continental basement (framework rock) (Figure 1). The small amount of sediment accumulated here is not compatible with a continuous history of accretion, which implies episodic phases of tectonic accretion, nonaccretion, and erosion [Bangs and Cande, 1997]. Melnick and Echtler [2006] argued that the high average sedimentation rate since the Pliocene linked to fast denudation of the Andes Cordillera and the steady decrease of the subduction rate of the incoming oceanic Nazca plate had shifted the margin from erosive to accretionary during the Pliocene. Similarly, Kukowski and Oncken [2006] suggested that the SC Chilean subduction zone has been in accretion or nonerosion mode since the Pliocene and it has experienced subduction erosion since at least the middle Miocene at rates similar to the north of the JFR. At present, the SC Chile margin shows indications that frontal and basal (underplating) accretion and sediment subduction are happening cotectonically [Bangs and Cande, 1997; Díaz-Naveas, 1999; Behrmann and Kopf, 2001].

[6] In order to better understand the processes of sediment accretion and subduction off $\mathrm{SC}$ Chile, we revisited the velocity structure off Isla de Chiloé (Chile at $\sim 43^{\circ} \mathrm{S}$ ) already studied by Scherwath et al. [2009]. In this new study we use joint refraction and reflection traveltime tomographic techniques to characterize in great detail the structure of the FAP and the backstop transition zone to the inner prism. The obtained velocity model is compared with nine other published seismic profiles along the Chile margin with the aim of investigating the variation of accretionary prism morphologies, thickness of the subduction channel, and structural diversity along the SC Chile margin.
[7] Detecting the location of the backstop region also has important implications in the division between aseismic and seismogenic segments along the plate interface, in particular the updip seismic/aseismic transition. Byrne et al. [1988] proposed that megathrust earthquakes do not rupture along the plate interface all the way to the plate boundary at the trench axis or deformation front but rather dissipate seaward of the backstop. They explained this in terms of the high pore fluid pressure within accretionary prisms that approach lithostatic pressure, resulting in a substantial decrease in effective normal stress. Low effective normal stress results in low shear strength along the subduction interface, which in turn means that the accretionary prism is not able to store the shear stress released as sudden slip during large earthquakes. Hence, the accretionary prism typically characterized by the presence of highly elevated pore fluid pressure should thus be expected to deform aseismically as is observed in a number of subduction zones [Byrne et al., 1988]. Therefore, the arcwardmost part of the accretionary prism (i.e., backstop) defines the seismic front which marks the deep end of the aseismic zone and the updip of the seismogenic zone. The location of the seismic front or backstop is crucial for making estimates of the maximum possible size of megathrust earthquakes along the plate boundary because it delimits the trenchward limit of the potential rupture area of these events. Furthermore, position of the updip limit exerts a strong control on tsunami generation; that is, the updip limit defined by the backstop marks the seawardmost extension of fault slip that has a direct impact on the potential uplifted seafloor area able to generate tsunamis. A backstop located close to the trench will thus favor large tsunami magnitudes, whereas a backstop far from the trench will allow for only small tsunami magnitudes.

[8] Within the past 50 years, Chile suffered two giant tsunamigenic earthquakes $\left(>M_{w}=8.5\right)$ : the largest ever recorded 1960 Valdivia earthquake $\left(M_{w}=9.5\right)$ and the recent 2010 Maule earthquake $\left(M_{w}=8.8\right)$ (Figure 2b). The 1960 earthquake ruptured over a length of almost $950 \mathrm{~km}$ from $37^{\circ} \mathrm{S}$ (near Mocha FZ) to $\sim 46^{\circ} \mathrm{S}$ near the CTJ [Barrientos and Ward, 1990; Moreno et al., 2009]. This event caused a trans-Pacific tsunami affecting, for instance, the Chilean and Hawaiian coasts with waves up to 25 and $11 \mathrm{~m}$, respectively. The 2010 Maule earthquake was the strongest earthquake affecting Chile since the giant 1960 earthquake, and it is the strongest earthquake worldwide since the 2004 Sumatra event $\left(M_{w} \sim 9.3\right)$. This event propagated northward and southward, reaching a final rupture length of $\sim 550 \mathrm{~km}$ $\left(\sim 33^{\circ}-39^{\circ} \mathrm{S}\right)$, which is roughly coincident with the subduction of the JFR and Mocha FZ (Figure 2b). The Maule tsunami badly hit the SC Chile coast with average waves of $10 \mathrm{~m}$ high. However, waves arriving at Easter Island located $3,510 \mathrm{~km}$ west from the epicenter reached a height of only 0.3-0.4 m. In Hawaii and Japan wave heights were even smaller and hence the 2010 regional tsunami was much smaller compared to the transoceanic 1960 tsunami. Thus, it becomes intriguing how the position of the updip seismic/ aseismic transition zone controls the efficiency of generating large-scale tsunamis. In this paper, we compare the deep crustal structures of the coseismic rupture zones between the 1960 and 2010 megathrust earthquakes, focusing on the 
(a)

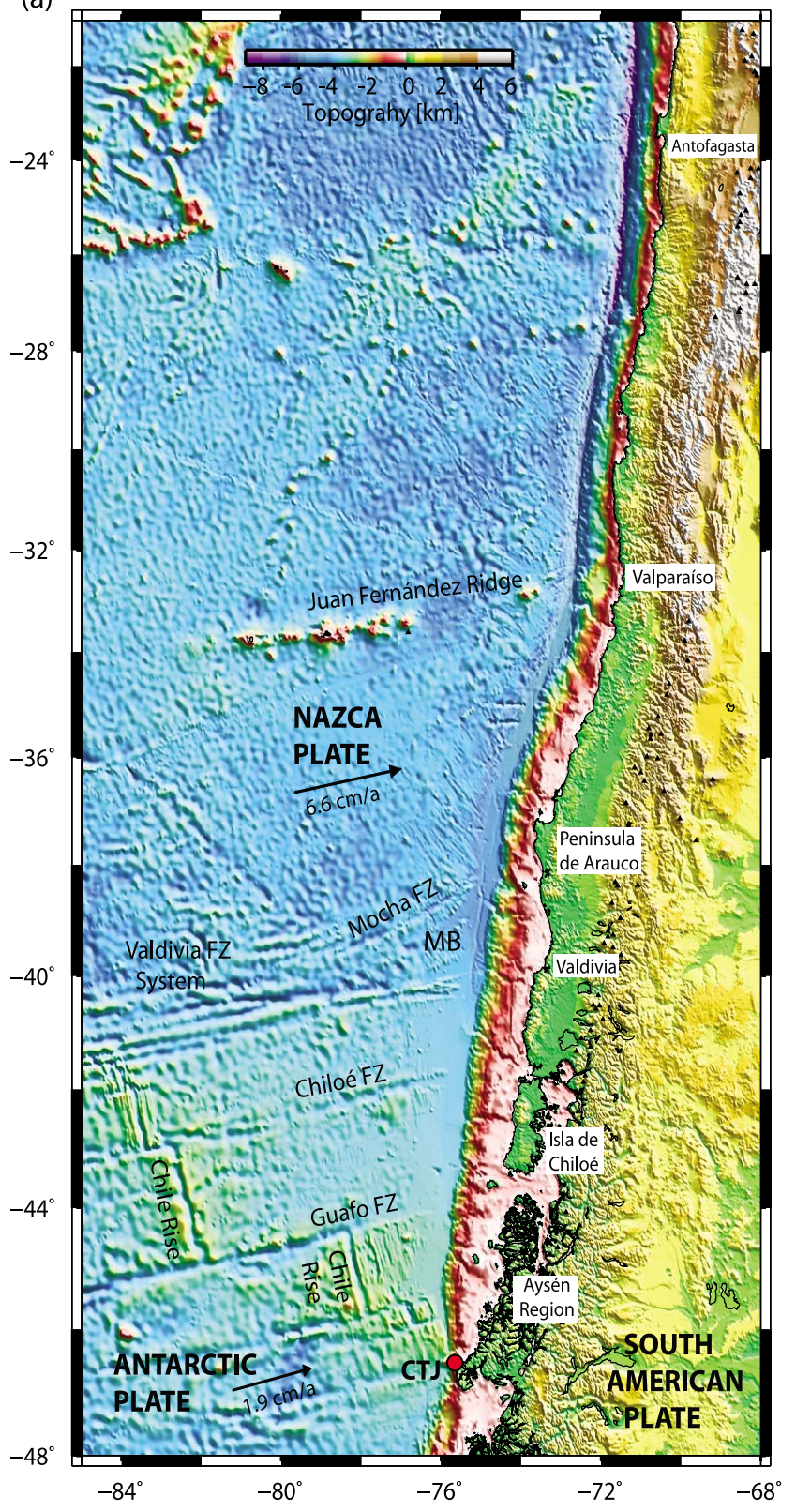

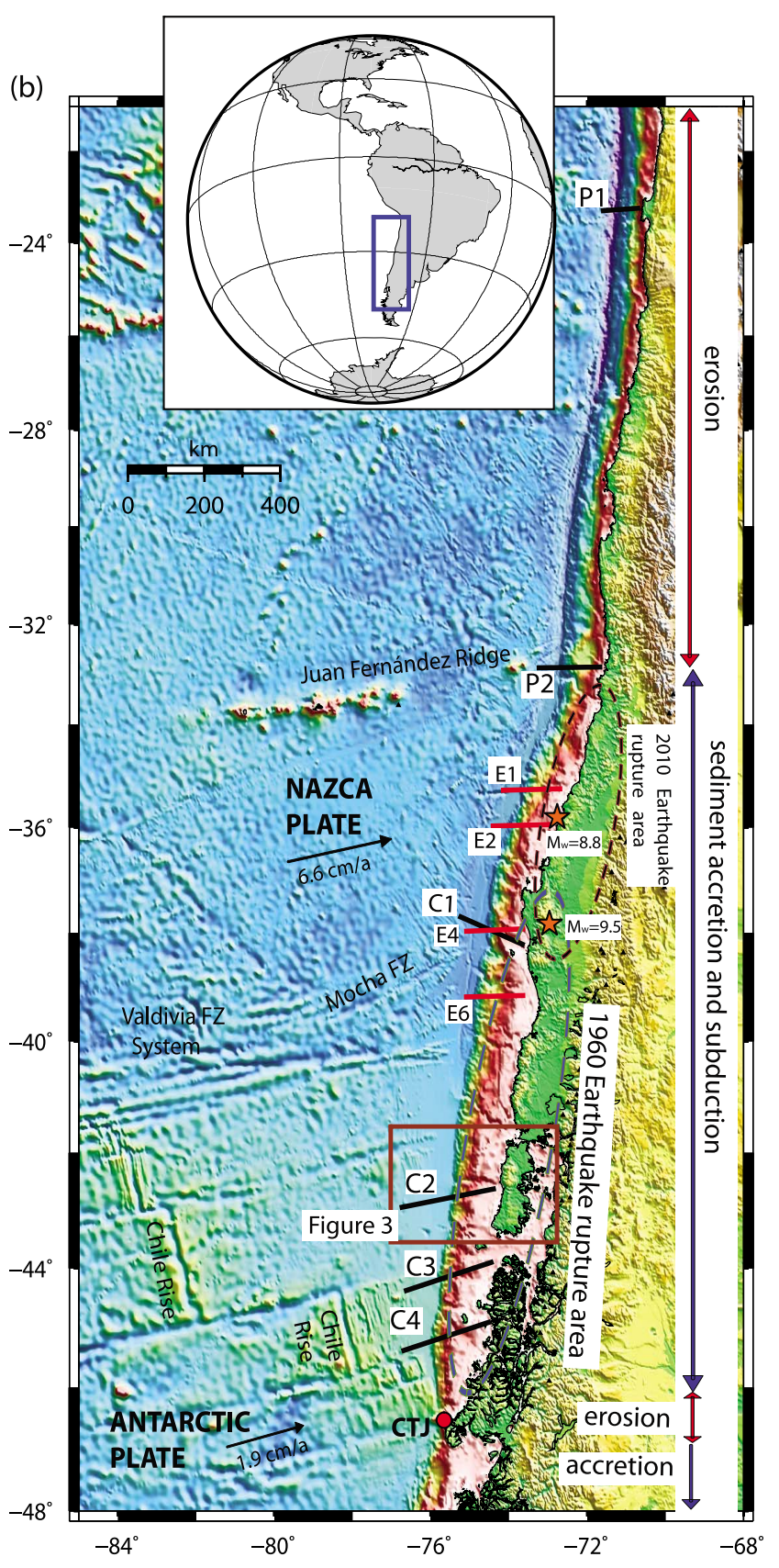

Figure 2. (a) Geodynamic setting of Nazca, Antarctic, and South America plates; plates join at the Chile triple junction (CTJ). The south central Chile margin is heavily sedimented and lies between the Juan Fernández Ridge (JFR) and Chile Rise spreading center. The study seismic profile C2 is located between the Chiloé and Guafo fracture zones (FZs) offshore Isla de Chiloé. The Chile trench and Mocha and Valdivia fracture zones define the Mocha block (MB) that separates young (0-25 Ma) and old (30-35 Ma) oceanic lithosphere south and north of it, respectively [Tebbens et al., 1997]. (b) Black lines denote the wide-angle seismic profiles studied by P1 [Patzwahl et al., 1999; Sallares and Ranero, 2005], P2 [Flueh et al., 1998; Zelt, 1999], C1 [Contreras-Reyes et al., 2008], and C2-C4 [Scherwath et al., 2009]. Red line corresponds to the multichannel seismic reflection lines (E1, E2, E4, and E6) processed by Bangs and Cande [1997] and Diaz-Naveas [1999]. Red-dotted and green-dotted ellipses denote the coseismic rupture zones of the 2010 and 1960 earthquakes, respectively [Moreno et al., 2010, 2009]. Solid orange stars indicate epicenters of the 2010 and 1960 events, respectively. 
backstop region to discuss its possible effect on earthquake and tsunami size.

[9] The amount of subducted sediment has also a strong influence on megathrust seismicity since the subduction channel might smooth the subduction interface, resulting in a homogeneous coupled region. It is expected that a large homogenous coupled region facilitates long, lateral rupture propagation [Ruff, 1989; Scholl et al., 2007; Scherwath et al., 2009] and hence the earthquake size. In this paper, we also discuss the effect of a thick subduction channel on megathrust seismicity. In summary, the first part of our study involves investigating possible variations of FAP sizes and subduction channel thicknesses along the SC Chile margin to gain insights into the processes of sediment accretion and subduction. The second part of this study compares the FAP size and subduction channel thickness between the rupture areas of the 1960 and 2010 earthquakes. Results are interpreted in terms of the impact of the updip limit and the subduction channel thickness on megathrust seismicity.

\section{Tectonic Setting}

[10] North of $\sim 34^{\circ} \mathrm{S}$, the incoming oceanic Nazca plate was formed at the Pacific-Nazca spreading center (East Pacific Rise) more than 35 Myr ago [Tebbens et al., 1997], whereas between $\sim 34^{\circ}$ and $46^{\circ} \mathrm{S}$ it was created at the NazcaAntarctic spreading center within the past $35 \mathrm{Ma}$ [Herron, 1981] (Figure 2a). At the trench $\left(\sim 33^{\circ}\right)$, the Juan Fernández hot spot ridge acts as a barrier for trench turbidites transport separating a sediment-starved trench axis to the north from a sediment-flooded axis to the south [von Huene et al., 1997]. The shallow and buoyant Chile Rise separates sediment to south and north of the CTJ [Bourgois et al., 2000]. The heavily sedimented trench $(1.5-2.5 \mathrm{~km}$ thick) between the JFR and CTJ is the result of high sedimentation rates since the Pliocene linked to glaciation/deglaciation and fast denudation of the Andes [e.g., Melnick and Echtler, 2006; Glodny et al., 2006]. The deposited material is mainly transported through deep canyons and redistributed within the trench from south to north [Thornburg and Kulm, 1987; Thornburg et al., 1990]. The submarine canyons are offshore prolongations of the main rivers of Pleistocene glacial valleys and cut across the continental shelf and slope [Gonzalez, 1989].

[11] From Arica $\left(\sim 18.4^{\circ} \mathrm{S}\right)$ to Valparaíso $\left(\sim 33^{\circ} \mathrm{S}\right)$, the ocean crust is thinly sedimented, and the trench axis is virtually empty of a turbidite sequence. The continental shelf trends N-NE to S-SW and is only 5 to $20 \mathrm{~km}$ wide. Fore-arc sedimentary basins of limited extension are present in this margin and probably are filled with Cenozoic sediment [Gonzalez, 1989]. The continental slope is steep and interrupted by structural terraces. The toe of the margin is truncated likely due to tectonic erosion along the underside of the upper plate from abrasive scraping by subducting horst and graben relief on the lower plate [von Huene and Ranero, 2003].

[12] From Valparaíso to the CTJ, the shelf has an average width of more than $35 \mathrm{~km}$, and in some sectors of the Itata $\left(\sim 38^{\circ} \mathrm{S}\right)$, Valdivia $\left(\sim 40^{\circ} \mathrm{S}\right)$, and Chiloé $\left(\sim 43^{\circ} \mathrm{S}\right)$, it has a width of 60 to $100 \mathrm{~km}$. Several large-fore-arc basin seg- ments contain thick sequences of Late Cretaceous and Cenozoic marine clastic sediment. The continental slope is broken by structural terraces on and overlain by a relatively thick sequence of sediment apron (500-1000 m). The continental shelf and slope are cut by a complex fault system and are furrowed by deep canyons formed in the outlets of the main rivers of Pleistocene glacial valleys [Gonzalez, 1989]. At the CTJ, the shelf is extremely narrow $(<5 \mathrm{~km}$ wide) due to the frontal and basal erosional processes linked to the collision of the Chile Rise with the margin [Behrmann et al., 1994; Bourgois et al., 1996].

\section{Configuration of the South Central Chile Margin}

[13] Figure 1b shows a typical scheme of the south central Chile margin. The present accretionary prism is 5 to $40 \mathrm{~km}$ wide, and it abuts the truncated continental basement (inner prism) that extends seaward from beneath the shelf [Bangs and Cande, 1997]. Melnick and Echtler [2006] and Kukowski and Oncken [2006] claim that the accretionary prism started to form as a response to a rapid increase of glacial age sediment supply to the trench during the middle Pliocene. According to Scholl and von Huene [2007], accreting margins are characterized by large and growing accretionary wedges $(>40 \mathrm{~km}$ width) formed over a long period of time (>10-20 Myr). These large accreted wedges are constructed of a middle prism of little-deforming older accreted material that is attached landward to the front of the rock framework of the fore arc's inner prism and seaward to a frontal prism of actively accreting and deforming material. Because the southern central Chile margin lacks a middle prism of any significant width and has a young FAP $(<6 \mathrm{Ma})$, this margin has been recently classified as nonaccretionary [Scholl and von Huene, 2007; von Huene et al., 2009].

[14] The continental basement that defines the inner prism (framework rock) have been studied inland by several authors [Mordojovich, 1974; Herve, 1976; Glodny et al., 2006] and it corresponds to the basement of the Coastal Cordillera. The Coastal Cordillera north of $\sim 38^{\circ} \mathrm{S}$ contains late Paleozoic arc granitoids that are associated with low $P / T$ metasediment ("Eastern Series"), whereas, further south, the Cordillera is mainly built by the Western Series paleowedge complex [e.g., Glodny et al., 2006]. The Paleozoic continental basement has been named in several ways, for instance, Paleozoic accretionary complex, Paleozoic continental metamorphic basement, or paleoaccretionary complex of Paleozoic age. This rock unit was deeply buried, and the now-exhumed rocks are $\sim 300$ Myr older than the present FAP (Figure 1b).

[15] Geophysical evidence showed the likely presence of a paleobackstop structure $10-40 \mathrm{~km}$ offshore off SC Chile $\left(38^{\circ}-45.5^{\circ} \mathrm{S}\right)$, using seismic data [Contreras-Reyes et al., 2008; Scherwath et al., 2009] and intraplate seismicity [Haberland et al., 2006, 2009; Lange et al., 2007]. The existence of a paleobackstop suggests a change of rock type and might be associated with the seaward edge of the Paleozoic continental metamorphic basement, whereas the inner block sandwiched between the present FAP and the paleobackstop may correspond to a paleoaccretionary complex (Figure 1b). Unfortunately, drilling did not sample this 


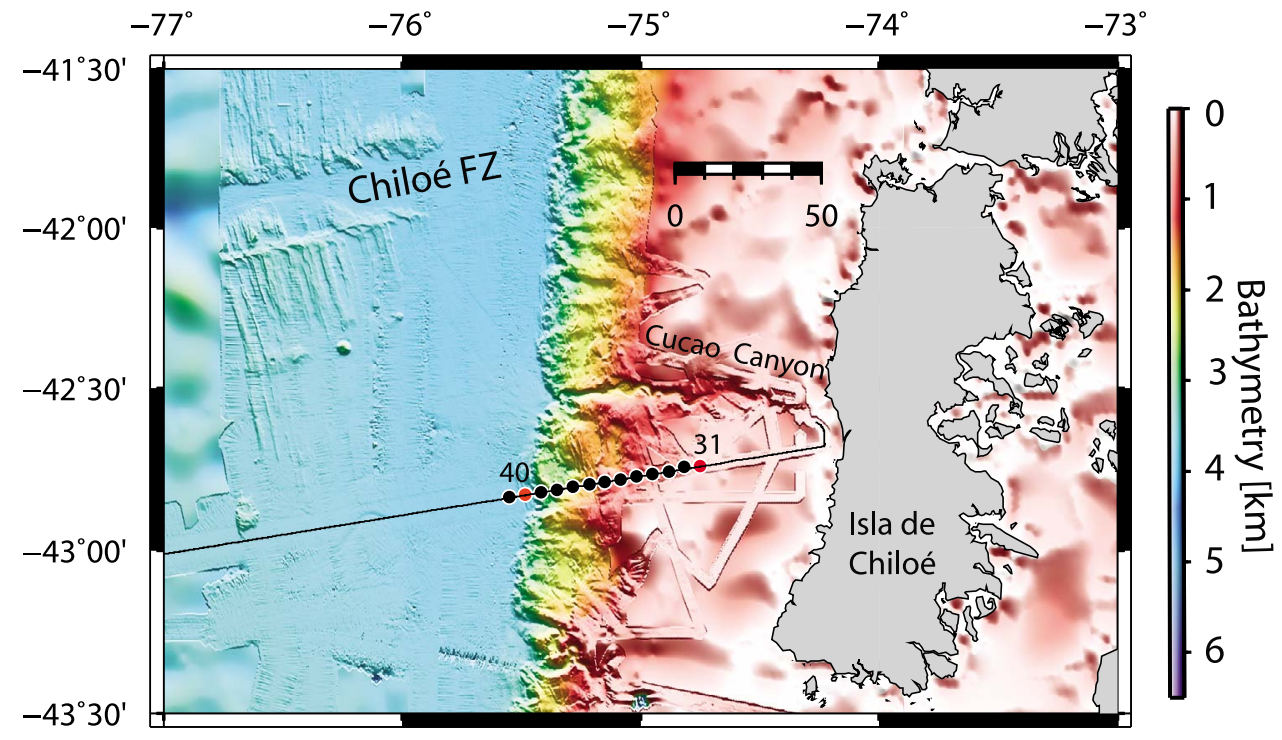

Figure 3. High-resolution bathymetric image of the seafloor off Isla de Chiloé from the R/V Sonne cruise SO181 [Scherwath et al., 2006]. Red dots indicate the two stations of which data examples are shown in Figure 4.

geological unit but is confined to coastal sites, where basement rocks are of Paleozoic age [Mordojovich, 1974]. On the basis of the location of exploratory wells studied by Mordojovich [1974], the Paleozoic basement rock found here is located landward of the seaward edge of the presumed paleobackstop structure. Therefore, the composition and age of the proposed paleoaccretionary complex still remains unclear. If the seismic imaged paleobackstop indeed defines a lithological discontinuity, then the inner prism (framework rock) can be composed of two main rock units: a submerged paleoaccretionary complex $(<300 \mathrm{Myr})$ and a Paleozoic continental metamorphic basement (Figure 1b). Due to the meta-sedimentary origin of the inner prism (framework rock) immediately arcward of the FAP, we will refer hereafter to this as the paleoaccretionary prism as is shown in Figure $1 \mathrm{~b}$.

\section{Seismic Structure of the Continental Margin off Isla de Chiloé}

[16] High-resolution seismic wide-angle data were collected across the plate boundary off SC Chile, along four major transects (corridors $\mathrm{C} 1-\mathrm{C} 4$, Figure 2b) [Flueh and Grevemeyer, 2005]. This paper presents seismic tomographic results of the continental part of corridor 2 of the TIPTEQ (from The Incoming Plate to Mega-thrust EarthQuake Processes) project [Scherwath et al., 2006]. Corridor 1 and the oceanic part of corridor 2 were already analyzed using joint refraction and reflection traveltime tomography by Contreras-Reyes et al. [2008] and Contreras-Reyes et al. [2007], respectively. Corridors 3-4 and the continental part of corridor 2 (Figures 2b and 3) were studied by Scherwath et al. [2009] using the ray-tracing code of Zelt and Smith [1992]. The code calculates traveltimes using asymptotic ray theory. In principle, the program allows iterative damped least-squares inversion of traveltimes. This approach, however, is strongly dependent on the model parameterization.
The number of layers along with the roughness of crustal interfaces makes it difficult to set up a model not biased by the parameterization. In order to reexamine the seismic structure of the continental part of corridor 2, we present a tomographic image of the margin offshore Isla de Chiloé using the joint refraction and reflection traveltime tomography code of Korenaga et al. [2000].

\subsection{Seismic Data}

[17] The seismic source for the refraction work was a cluster of $8 \times 8 \mathrm{~L} \mathrm{G}$ guns, providing a total volume of $64 \mathrm{~L}$ for each shot. This source was fired at a time interval of $60 \mathrm{~s}$, which corresponds to an average shot spacing of $150 \mathrm{~m}$. Shots were recorded with $11 \mathrm{OBH} / \mathrm{S}$ (ocean bottom hydrophones/seismometers) spaced at a average distance of $5.5 \mathrm{~km}$. The signal-to-noise ratio obtained for most of the stations is high (see Figure 4). We have recorded crustal refractions $\left(P_{g}\right)$, including refractions through trench sediment, Moho wide-angle reflections $\left(P_{m} P\right)$, upper mantle refractions $\left(P_{n}\right)$, and reflections from the top of the oceanic crust $\left(P_{\text {toc }} P\right)$ with excellent quality. Two examples of seismic record sections are shown in Figure 4, with their respective seismic phases identified. Figure 4 a shows the seismic record of OBH 40 situated $5 \mathrm{~km}$ landward from the deformation front, which is characterized by clear refractions throughout the trench fill, and $P_{\text {toc }} P$ arrivals with apparent velocity $<3.5 \mathrm{~km} / \mathrm{s}$. In addition, oceanic crustal and mantle refractions and Moho reflections of excellent quality were also recorded at the western branch of the seismic station. The seismic data recorded at the eastern branch provide coverage of accreted sediment and continental and oceanic crust. Figure $4 \mathrm{~b}$ shows an example of record section OBH 31 positioned above the depocenter of the Chiloé forearc basin (see Figure 3 for location). The OBH data provide coverage of shelf sediment and the metasedimentary conti- 
(a)
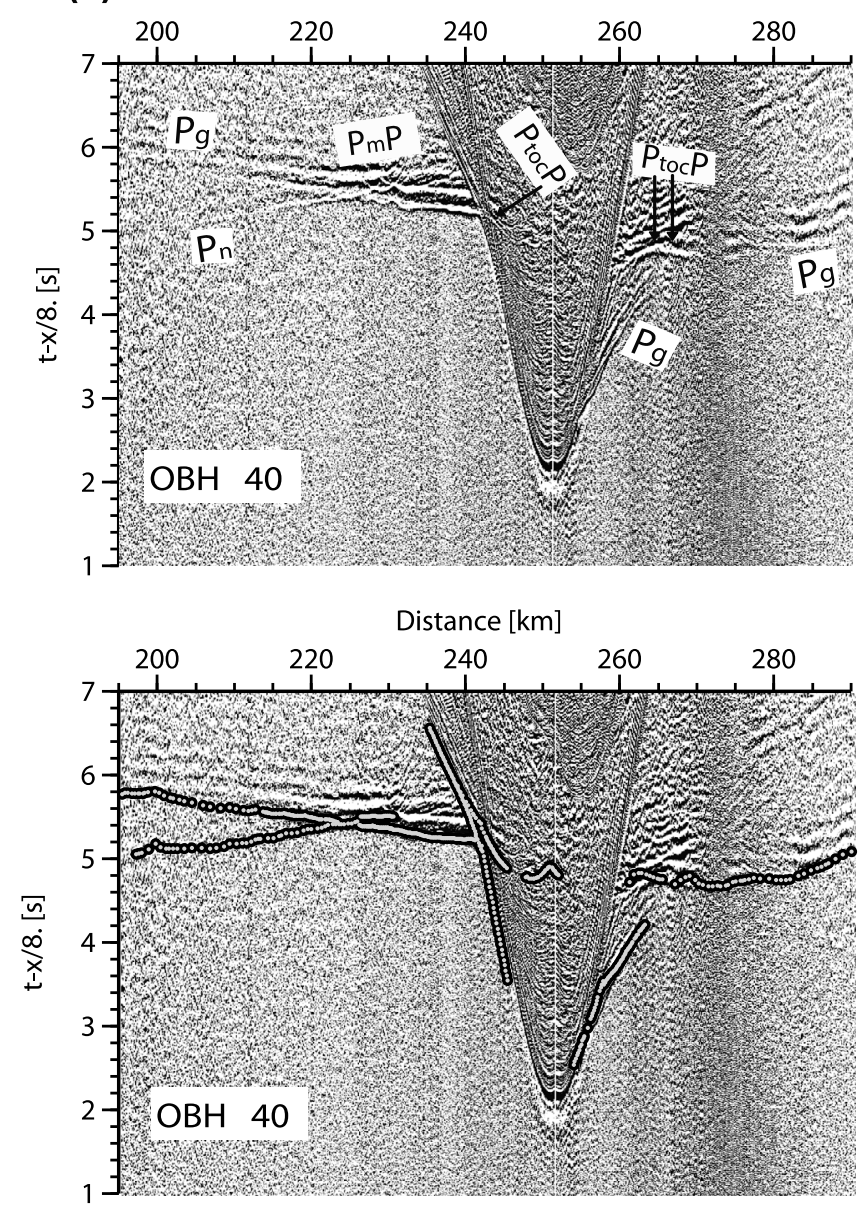
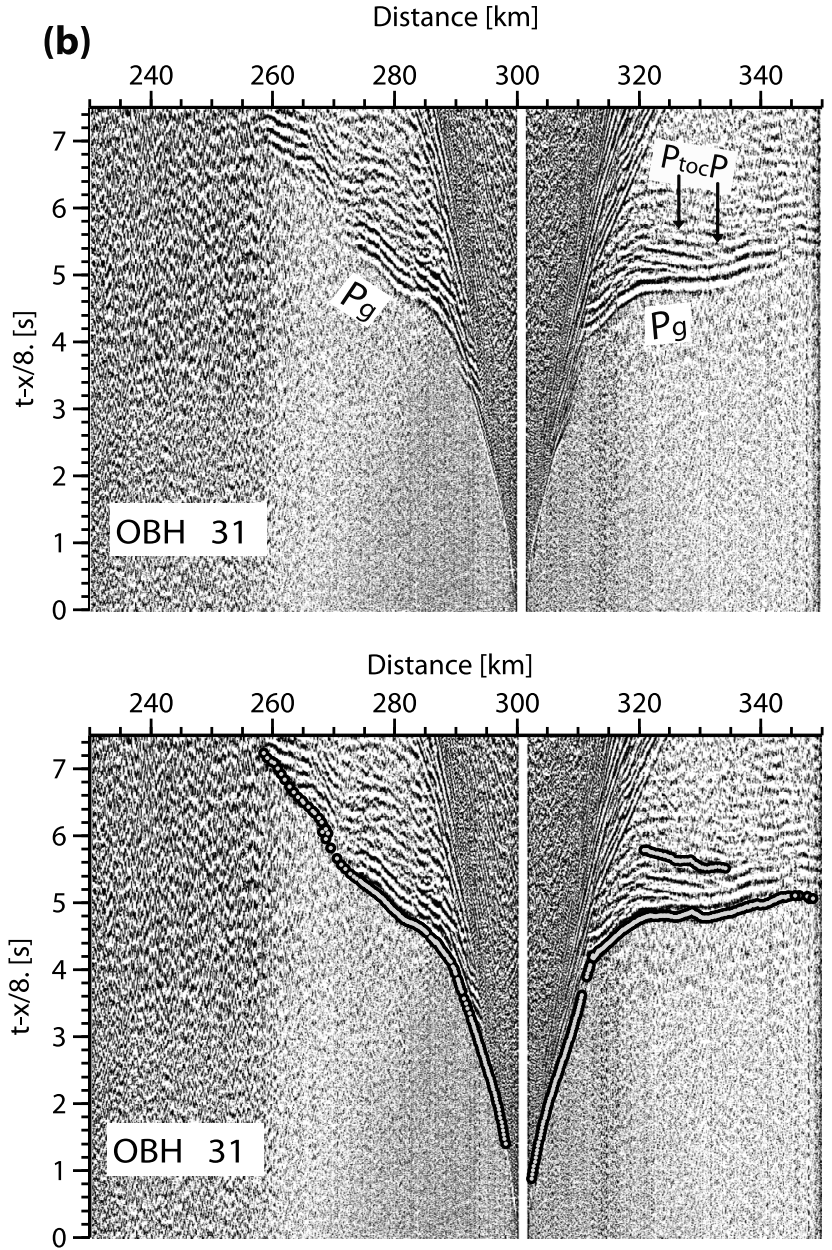

Figure 4. Examples of wide-angle seismic data with predicted traveltimes (gray circles), which are computed based on the velocity model presented in Figure 5c. (a) OBH 40 located in the vinicinity of the deformation front, (b) OBH 31 above the depocenter of the Chiloe forearc basin (see Figure 3 for location).

nental crust. Reflections from the top of the oceanic crust are also evident and constrain the location of the plate boundary (Figure 4b). A striking feature of the data set is the rapid increase of apparent $P_{g}$ velocities from profile-km $\sim 320$, suggesting a strong horizontal velocity gradient (Figure $4 b$ ).

[18] Picking of the seismic phases was done manually, and picking errors were assumed to be half a period of one arrival, to account for a possible systematic shift in the arrival identification, and were weighted according to the phase quality. Detailed information regarding average pick- ing uncertainties and number of picks are summarized in Table 1.

\subsection{Traveltime Tomography Scheme}

[19] We obtained the $P$-wave velocity-depth structure using the joint refraction and reflection traveltime inversion method of Korenaga et al. [2000]. This method allows joint inversion of seismic refraction and reflection traveltime data for a 2-D velocity field. Traveltimes and raypaths are calculated using a hybrid ray-tracing scheme based on the

Table 1. $P_{g 1}$ and $P_{g 2}$ Are the Arrivals Refractions Through the Continental and Oceanic Crust, Respectively ${ }^{\mathrm{a}}$

\begin{tabular}{lcccccc}
\hline Phase & $\Delta T_{\text {avg }}(\mathrm{ms})$ & $\begin{array}{c}\text { Reference Model } \\
T_{\text {RMS }}(\mathrm{ms})\end{array}$ & $\begin{array}{c}\text { Reference } \\
\text { Model } \chi^{2}\end{array}$ & $\begin{array}{c}\text { Average Final Model } \\
T_{\text {RMS }}(\mathrm{ms})\end{array}$ & $\begin{array}{c}\text { Average Final } \\
\text { Model } \chi^{2}\end{array}$ & $\begin{array}{c}\text { Number of } \\
\text { Picks }\end{array}$ \\
\hline$P_{g 1}$ & 55 & 233.56 & 17.23 & 52.55 & 0.71 & 2614 \\
$P_{\text {toc }} P$ & 75 & 201.51 & 10.32 & 77.75 & 1.42 & 306 \\
$P_{g 2}$ & 60 & 70.55 & 1.12 & 55.63 & 0.68 & 763 \\
$P_{m} P$ & 70 & 101.34 & 2.05 & 77.63 & 1.20 & 587 \\
$P_{n}$ & 75 & 147.98 & 3.93 & 74.69 & 1.05 & 177 \\
\hline
\end{tabular}

${ }^{\mathrm{a}} \Delta T_{\text {avg }}$, average traveltime uncertainty; $T_{\mathrm{RMS}}$, root-mean-square traveltime misfit; and $\chi^{2}$, chi-square parameter. 
graph method and the local ray-bending refinement [van Avendonk et al., 1998]. Smoothing constraints using predefined correlation lengths and optimized damping constraints for the model parameters are used to regularize an iterative linearized inversion [Korenaga et al., 2000].

[20] The velocity model consists of the following geological units, (1) water, (2) sediment, (3) marine fore-arc basement, (4) oceanic crust, and (5) upper oceanic mantle. To derive the velocity depth model, the water depth was taken from the known bathymetry, which remained fixed during the inversion. Thickness of the sediment unit overlying the oceanic plate seaward of the trench wedge was obtained by picking and converting the vertical incidence reflections from the time-migrated MCS data, using a constant velocity of $1.7 \mathrm{~km} / \mathrm{s}$ [Contreras-Reyes et al., 2007]. To obtain the velocity and thickness of the sedimentary fore-arc basin, a combined approach using sedimentary refractions through the basin and reflections from the top of the oceanic was applied. Refractions through the trench fill and fore-arc "crust" $P_{g}$ and reflected $P_{\text {toc }} P$ phases were used to directly invert for the velocity structure of the marine fore arc and geometry of the top of the oceanic plate. Inverted velocities and the depth of the plate boundary (igneous oceanic basement) were then held fixed in the following iterative inversions. The inner oceanic crust structure was inverted using $P_{g}$ phases (first and later arrivals) to their maximum offset and $P_{m} P$ phases in order to derive the velocity field and Moho depth. Similarly, the crustal velocities and Moho depth remained fixed for the next step of the inversion, where the upper mantle velocities were derived using oceanic $P_{n}$ phases.

\subsection{Reference Model and Inversion Parameters}

[21] We used two floating reflectors to model (1) the interplate boundary beneath the continental margin and (2) the oceanic Moho. The initial geometry and velocity field were based on the forward model of Scherwath et al. [2009]. The root-mean-square traveltime residuals $\left(T_{\mathrm{RMS}}\right)$ obtained with the $2-\mathrm{D}$ reference model are presented in Table 1 for each seismic phase. The horizontal grid spacing of the model used for the velocity inversion is $0.5 \mathrm{~km}$, whereas the vertical grid spacing is varied from $0.1 \mathrm{~km}$ at the top of the model to $1 \mathrm{~km}$ at the bottom. Depth nodes defining the plate boundary and Moho reflectors are spaced at 1 and $2 \mathrm{~km}$, respectively. We used horizontal correlation lengths ranging from $2 \mathrm{~km}$ at the top to $10 \mathrm{~km}$ at the bottom of the model, and vertical correlation lengths varying from $0.1 \mathrm{~km}$ at the top to $2.5 \mathrm{~km}$ at the bottom. Different tests showed that varying the correlations lengths by $50 \%$ does not significantly affect the solution. Because of the trade-off between correlation lengths and smoothing weights, we tried to use shorter correlation lengths and larger smoothing weights to reduce memory requirements [Korenaga et al., 2000]. Depth and velocity nodes are equally weighted in the refraction and reflection traveltime inversions.

\subsection{Final and Uncertainty Velocity Models}

[22] Tests with several starting models converge to nearly the same final model. In order to study the accuracy of the final model, we employed the Monte Carlo method [Korenaga et al., 2000]. The procedure to estimate velocitydepth uncertainties consisted of randomly perturbing velocities and reflector depths of our reference model (Figure 5a). We generated 10 random initial velocity models by adding randomly distributed smooth perturbations. The 2-D starting velocity models were obtained by adding smooth perturbations randomly distributed (maximum velocities perturbations of $\pm 0.4 \mathrm{~km} / \mathrm{s}$ at the top and $\pm 0.3 \mathrm{~km} / \mathrm{s}$ at the bottom of the model, with wavelength perturbations of $10 \mathrm{~km}$ horizontally and 0.5 vertically). The initial geometry of the Moho reflector was randomly varied within a range of $\pm 3 \mathrm{~km}$. In addition to the perturbed reference models we produced 10 so-called noisy arrival time sets constructed by adding random phase errors $( \pm 50 \mathrm{~ms})$ and common receiver errors $( \pm 50 \mathrm{~ms})$ to the original data set. Then we performed a tomographic inversion for each velocity model with one noisy data set (resulting in a total of 100 final models) to estimate not only the dependence of the solution on the reference model but also the effect of phase arrival time picking errors. The stopping criterion for each inversion was $\chi^{2} \leq 1$. Figure $5 \mathrm{c}$ shows the average velocity-depth model from the 100 final models, and detailed information regarding root-mean-square traveltime misfits $T_{\mathrm{RMS}}$ and $\chi^{2}$ parameters for the final average model is summarized in Table 1. The calculated velocity uncertainties are shown in Figure $5 \mathrm{~d}$ and is well constrained in the entire velocity model, except in the upper and seaward part of the oceanic crust. Approximately $40 \mathrm{~km}$ landward from the deformation front, velocity-uncertainty values at the bottom of the upper plate increase to values of $0.4 \mathrm{~km} / \mathrm{s}$ due to the reduced data coverage (Figure 5b).

\subsection{Seismic Results}

[23] The final average model shown in Figure $5 \mathrm{c}$ is characterized by typical sedimentary velocities for the forearc basin, trench fill, and FAP (1.7-3.5 km/s). Three main units can be identified: (1) a $\sim 7 \mathrm{~km}$ wide FAP with seismic velocities ranging from 1.7 to $3.5 \mathrm{~km} / \mathrm{s}$; (2) an $\sim 85 \mathrm{~km}$ wide block with $V_{p}=4.5-5.5 \mathrm{~km} / \mathrm{s}$, perhaps representing a paleoaccretionary prism; and (3) the truncated seaward edge of the Paleozoic continental framework with $V_{p} \geq 5.5 \mathrm{~km} / \mathrm{s}$ at $\sim 90 \mathrm{~km}$ landward of the deformation front (see section 3 and Figure 1). The main features of the velocity model shown in Figure 5 are similar to those found by Scherwath et al. [2009], who used the ray-tracing code of Zelt and Smith [1992]. However, there are some differences such as the morphology of the slope and shelf sediment as well as the angle of subduction. Our new results show that the seismic reflectors associated with the interface of the forearc basin-paleoaccretionary prism and top of the subduction oceanic crust are smooth (contra Scherwath et al. [2009], who calculated "rough" reflectors). The most striking feature detected in both models is the sharp velocity contrast at $\sim 7 \mathrm{~km}$ from the deformation front that we interpreted here as the active backstop front and defines the arcward end of the small FAP. Further discussion concerning the tectonic implications of the velocity model is discussed in section 5.1 . 
(a)
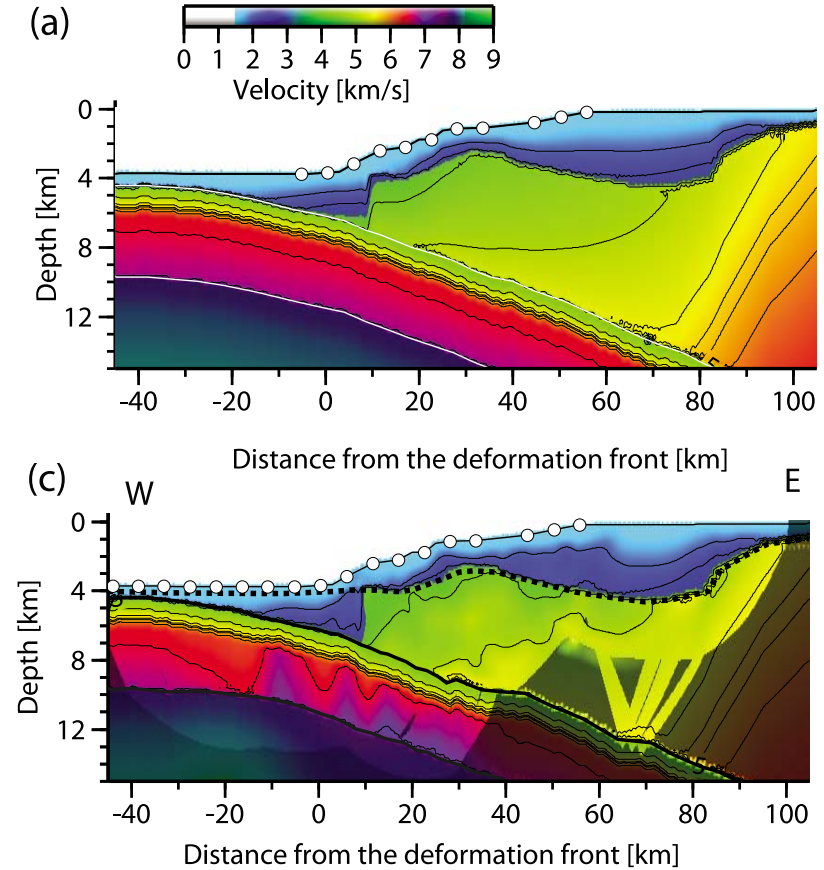

(b)

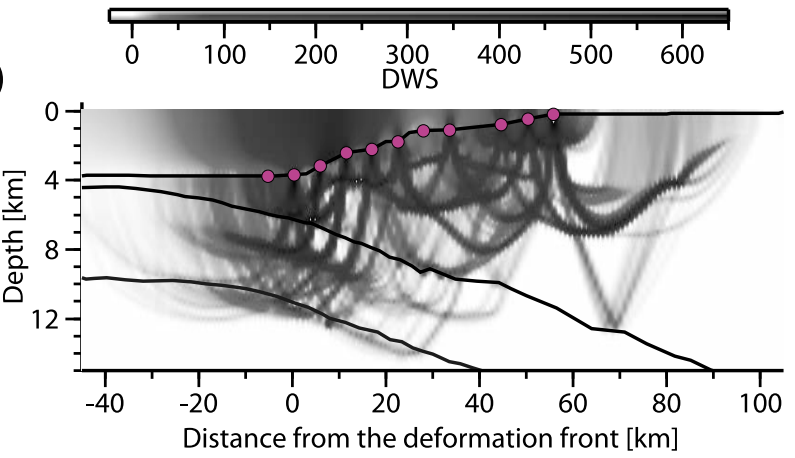

(d)

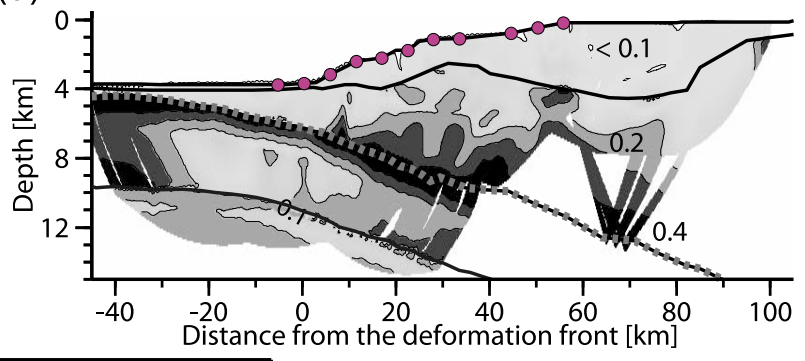

$\begin{array}{lllllll}0.0 & 0.1 & 0.2 & 0.3 & 0.4 & 0.5 & 0.6\end{array}$

standard deviation $[\mathrm{km} / \mathrm{s}$ ]

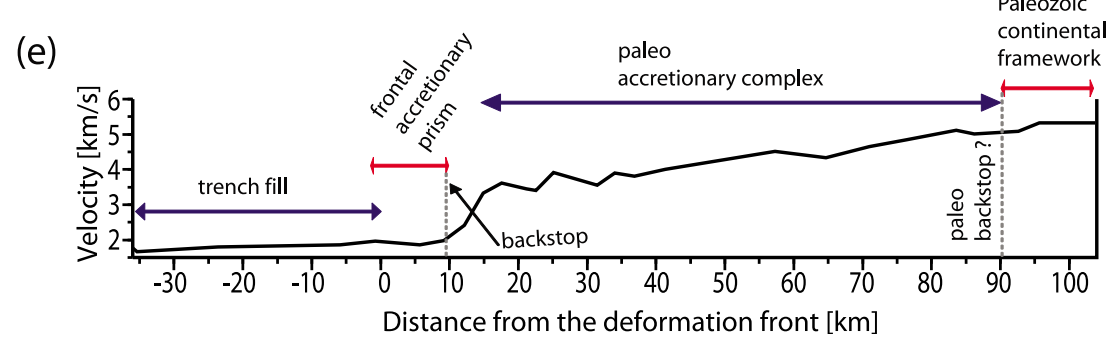

Figure 5. Result of tomographic inversion. (a) Initial velocity model that was constructed by using forward modeling and the velocity model of Scherwath et al. [2009]. (b) Derivative Weight Sum (DWS) for rays traveling throughout model shown in Figure 5c. (c) Final velocity-depth model derived by averaging all Monte Carlo ensembles. (d) Velocity uncertainty model after Monte Carlo type realizations. (e) Extracted velocities along the thick dotted black line shown in Figure 5c, which 5-10 km landward of the deformation front corresponds to the uppermost basement velocities below the slope and shelf sediment. Note the strong horizontal velocity gradient $5-10 \mathrm{~km}$ landward of the deformation front, which is interpreted as the backstop or landward edge of the frontal accretionary prism.

\subsection{Velocity Model Assessment}

[24] To assess the effect of alternative starting models on the stability of the final tomographic output and the robustness of the main features shown in the final velocity model (Figure $5 \mathrm{c}$ ), we conducted a test on different initial models. The objective is to demonstrate that the location of the active backstop measured from the deformation front and FAP size is independent on the initial model. We examine the output models derived from the seismic tomography by assuming two different starting models. The first initial model is assumed to be composed by of a marine fore arc lacking a FAP with typical sedimentary velocities $(2.0-3.5 \mathrm{~km} / \mathrm{s})$. Consistently the location of the velocity contrast is directed at the deformation front, which simulates the transition from the trench sediment to the inner prism (framework rock) (Figure 6a). The second initial model is the "opposite"; that is, we suppose a relative large FAP $40 \mathrm{~km}$ (with $V_{p}=1.7-3.5 \mathrm{~km} / \mathrm{s}$ ) and an active backstop with a sharp horizontal velocity contrast located at $40 \mathrm{~km}$ from the deformation front (Figure 6c). The $T_{\mathrm{RMS}}$ for both initial models is higher than $200 \mathrm{~ms}$ already revealing the implausible velocity model solutions. The final tomographic models for both starting models are shown in Figures $6 \mathrm{~b}$ and $6 \mathrm{~d}$. The inversion outputs display almost identical results for each input especially in the vicinity of the deformation front, where the ray coverage density is higher (Figure 5b). The small size of the FAP with seismic 


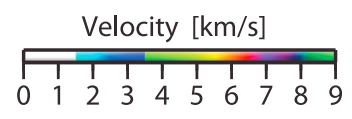

(a)
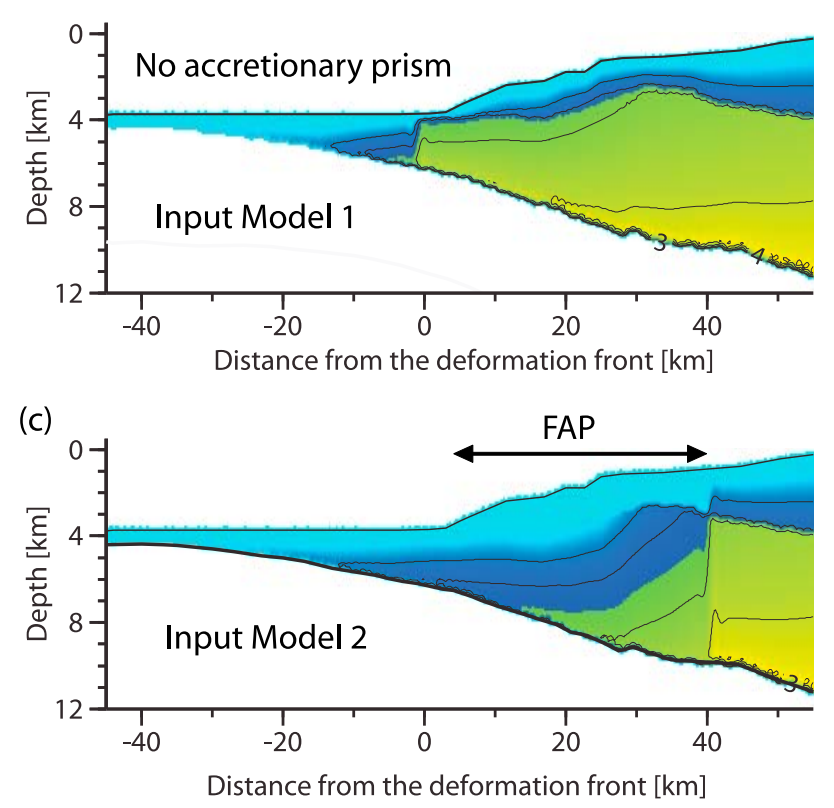

(b)

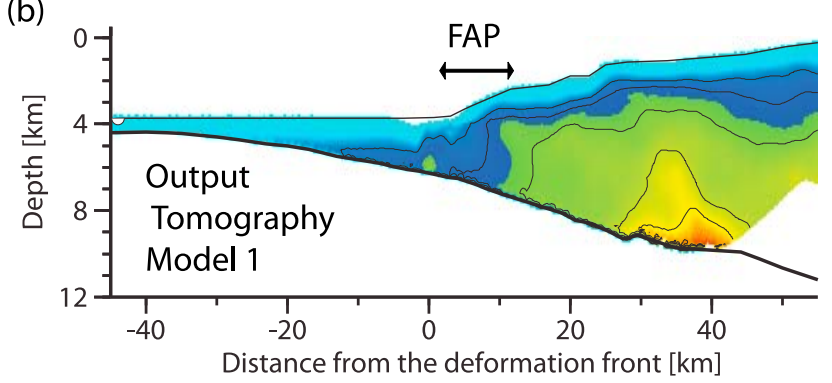

(d)

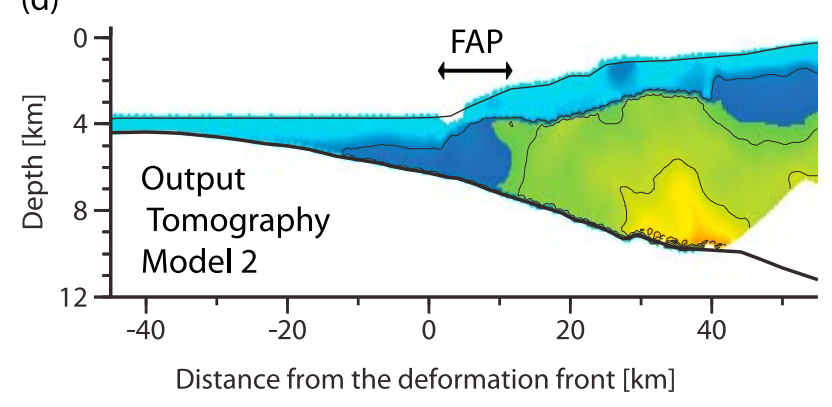

Figure 6. (a and c) Assessment of different starting models on the inversion using crustal arrivals within the overriding plate. (b and d) Tomographic outputs for these two input models. The input model (Figure 6a) is characterized by a margin lacking a frontal accretionary prism (FAP) with velocities $>4.0 \mathrm{~km} / \mathrm{s}$ landward of the deformation front while the starting model shown in Figure $6 \mathrm{c}$ simulates a margin with a $40 \mathrm{~km}$ wide FAP. The inversion outputs display almost identical results for each input in the vicinity of the deformation front. The precense of a very small FAP with seismic velocities $<4.0 \mathrm{~km} / \mathrm{s}$ arcward of the deformation front is evident for both final models. The high resolution of the seismic data images the active backtop region seaward of the FAP.

velocities lower than $4.0 \mathrm{~km} / \mathrm{s}$ landward of the deformation front is evident for both final models as well as the location of the active backstop. The final models at $\sim 40 \mathrm{~km}$ landward from the deformation beneath the fore-arc basin show a certain shape deterioration (Figures $6 \mathrm{~b}$ and $6 \mathrm{~d}$ ). Nevertheless, the results indicate that the data coverage yields a sufficiently high resolution to solve the size of the FAP with typical sedimentary velocities as well as the location of the active backstop region.

[25] A similar approach is used to demonstrate that the dip of the backstop is independent on the initial model. We examine the output models derived from the seismic tomography by assuming three different starting models with different backstop dips. Figure 7 shows three different input models with different backstop geometries at the real scale. The inversion outputs display almost identical results for each input, particularly a steep backstop dipping slightly trenchward $\left(80^{\circ}-90^{\circ}\right)$. The results indicate that the data coverage yields a sufficiently high resolution to solve the dip and location of the backstop.

\section{Discussion}

\subsection{Margin Structure off Isla de Chiloé}

[26] The margin off Isla de Chiloé is characterized by a broad sedimented trench, due to the large extension of tur- bidite deposits seaward reaching distances as far as $250 \mathrm{~km}$ from the trench axis [Contreras-Reyes et al., 2007]. Trench sediment was mainly delivered during late Cenozoic glaciations with a rapid sedimentation rate [Bangs and Cande, 1997; Kukowski and Oncken, 2006]. Another efficient mechanism for turbidites transport is along the prominent Cucao canyon, which is characterized by a deep incision eroding the fore-arc basin and the steep continental slope (Figure 8). The continental shelf is broad and trapped a huge volume of sediment (up to $4 \mathrm{~km}$ thick) [Gonzalez, 1989; Scherwath et al., 2009].The Chiloé fore-arc basin extends from $41.5^{\circ} \mathrm{S}$ down to the CTJ and consists mainly of Mesozoic to possibly Late Cretaceous marine clastics, overlain by up to $1000 \mathrm{~m}$ of Tertiaty and up to $500 \mathrm{~m}$ of Pliocene to Quaternary clastics [Gonzalez, 1989].

[27] The imaged FAP is approximately $7 \mathrm{~km}$ wide (Figure 8) and hence much smaller than the FAP imaged off Peninsula de Arauco at $\sim 38^{\circ} \mathrm{S} \quad(\sim 15-20 \mathrm{~km}$ wide) [Contreras-Reyes et al., 2008] and south of the JFR at $\sim 33^{\circ} \mathrm{S}$ ( 20-30 km wide) [Flueh et al., 1998; Zelt, 1999]. The size of the FAP imaged off Isla de Chiloé is similar to the imaged FAP by Scherwath et al. [2009] off the Aysén region at $\sim 200 \mathrm{~km}$ north of the CTJ and $\sim 100$ south of corridor 2 (Figures $2 b$ and 9). The imaged FAP off Isla de Chiloé is 
(a)

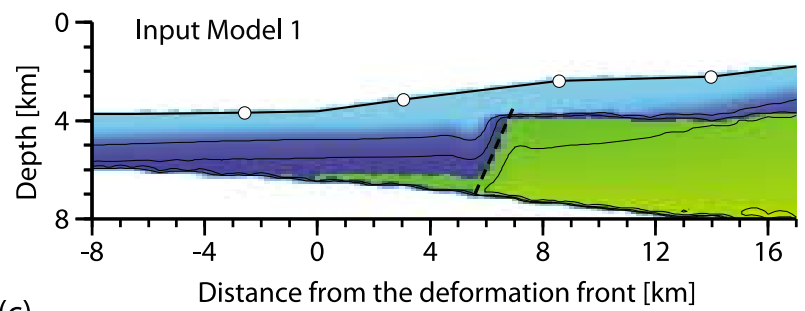

(c)

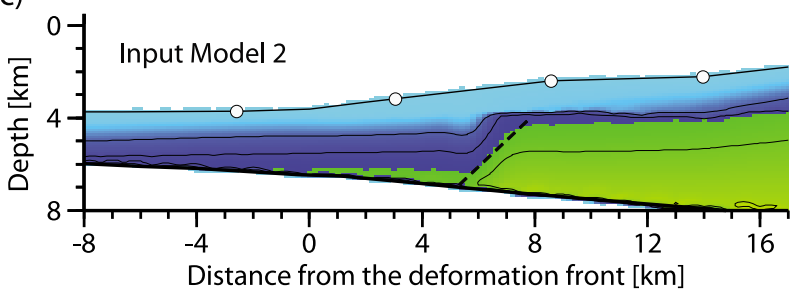

(e)

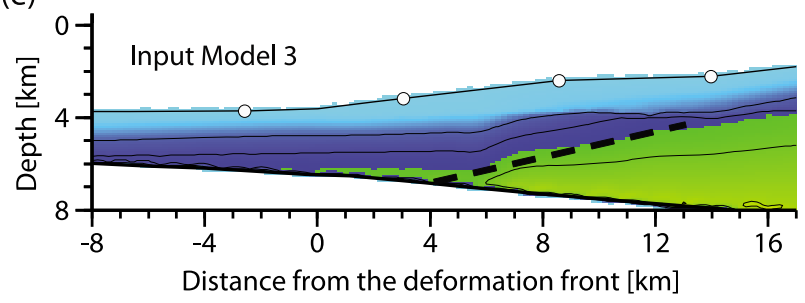

(b)

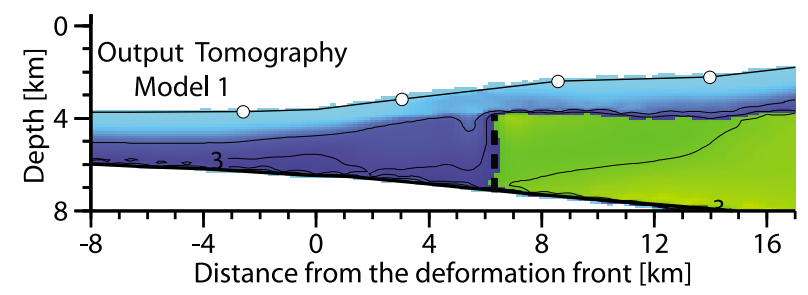

(d)

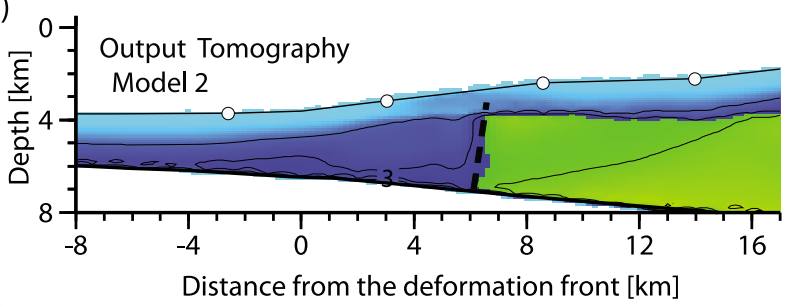

(f)

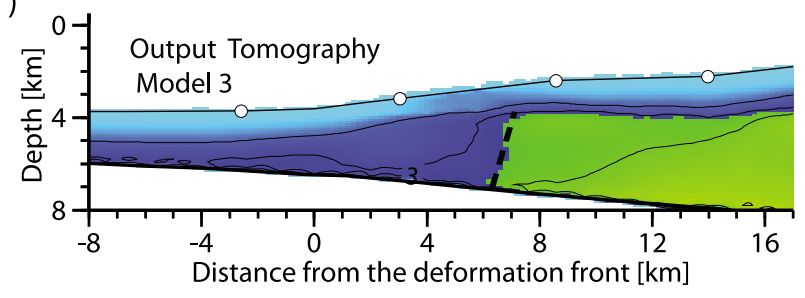

$$
\begin{array}{llllllllll}
\hline & 1 & & 1 & & 1 & & 1 & & \\
0 & 1 & 2 & 3 & 4 & 5 & 6 & 7 & 8 & 9 \\
& &
\end{array}
$$

Figure 7. (a, c, and e) Assessment of different starting models on the inversion using crustal arrivals within the overriding plate. (b, d, and f) Tomographic outputs for these three input models. The input models characterized by backstop-dip of $\sim 75^{\circ}$ (Figure $7 \mathrm{a}$ ), $\sim 60^{\circ}$ (Figure $7 \mathrm{c}$ ), and $\sim 40^{\circ}$ (Figure 7e). Dotted lines denote the location of the backstop. The inversion outputs display almost identical results for each input showing a steep backstop which slightly dips trenchward.

bounded at the east by a backstop region characterized by an abrupt increase of seismic velocities (Figures 5-8). It is also possible that the velocity fabric revealed on Figures 5-8 reflect a seaward increasing structural disintegration and disruption of the metamorphic rock sequence of the margin's inner basement, as was imaged for the Colombia-Ecuador margin by Collot et al. [2008]. However, since the horizontal velocity gradient is very high, this suggests a change in rocktype rather than a progressive disruption of the metamorphic rock sequence of the margin's inner basement. Otherwise, we should detect a progressive landward increase of velocity. Therefore, the sharpness of this velocity-contrast rules out a progressive trenchward increase of fracturing intensity of the margin's inner basement. Sharp velocity contrasts interpreted as backstops have also been imaged with seismic refraction data off Valparaíso [Flueh et al., 1998], the southern Peninsula de Arauco [Contreras-Reyes et al., 2008], and the Aysén region [Scherwath et al., 2009]. Similar features have been detected in other subduction zones such as Cascadia [Gerdom et al., 2000] and Sumatra-Andaman [Klingelhoefer et al., 2010]. The nearly vertical seaward termination of the basement framework off Isla de Chiloé shown in Figures 5 and 8 corresponds to backstops of type III according to the classification of Byrne et al. [1993]. This abrupt lithological discontinuity could had been formed due to previous episodes of strong frontal erosion at the base of the basement framework causing its nearly vertical seaward termination.

[28] Another abrupt increase of seismic velocities roughly $90 \mathrm{~km}$ landward of the deformation front indicates a change of rock type (Figure 8a) and might be associated with the seaward edge of the Paleozoic continental framework which is part of the Coastal Cordillera [Mordojovich, 1974]. The inner wedge sandwiched between the present FAP and this seismic "boundary" may correspond to a paleoaccretionary prism (see section 3). It is interesting to note that the presence of a similar seismic "boundary" at roughly the same distance from the deformation front $(\sim 80 \mathrm{~km})$ has been observed along profiles C1 [Contreras-Reyes et al., 2008], C3, and C4 [Scherwath et al., 2009] and thus may form an integral part of the marine fore arc in south Chile. The paleoaccretionary prism has a higher degree of consolidation and lithification than the FAP but is lower than the Paleozoic continental framework, which was formed under high $P / T$ conditions at great depths and is now exhumed. Alternatively, the unit interpreted as a paleoaccretionary prism might be part of the continental framework deformed and metamorphosed during a phase of tectonic erosion. However, the remarkable high lateral velocity gradient from $5.0 \mathrm{~km} / \mathrm{s}$ to 

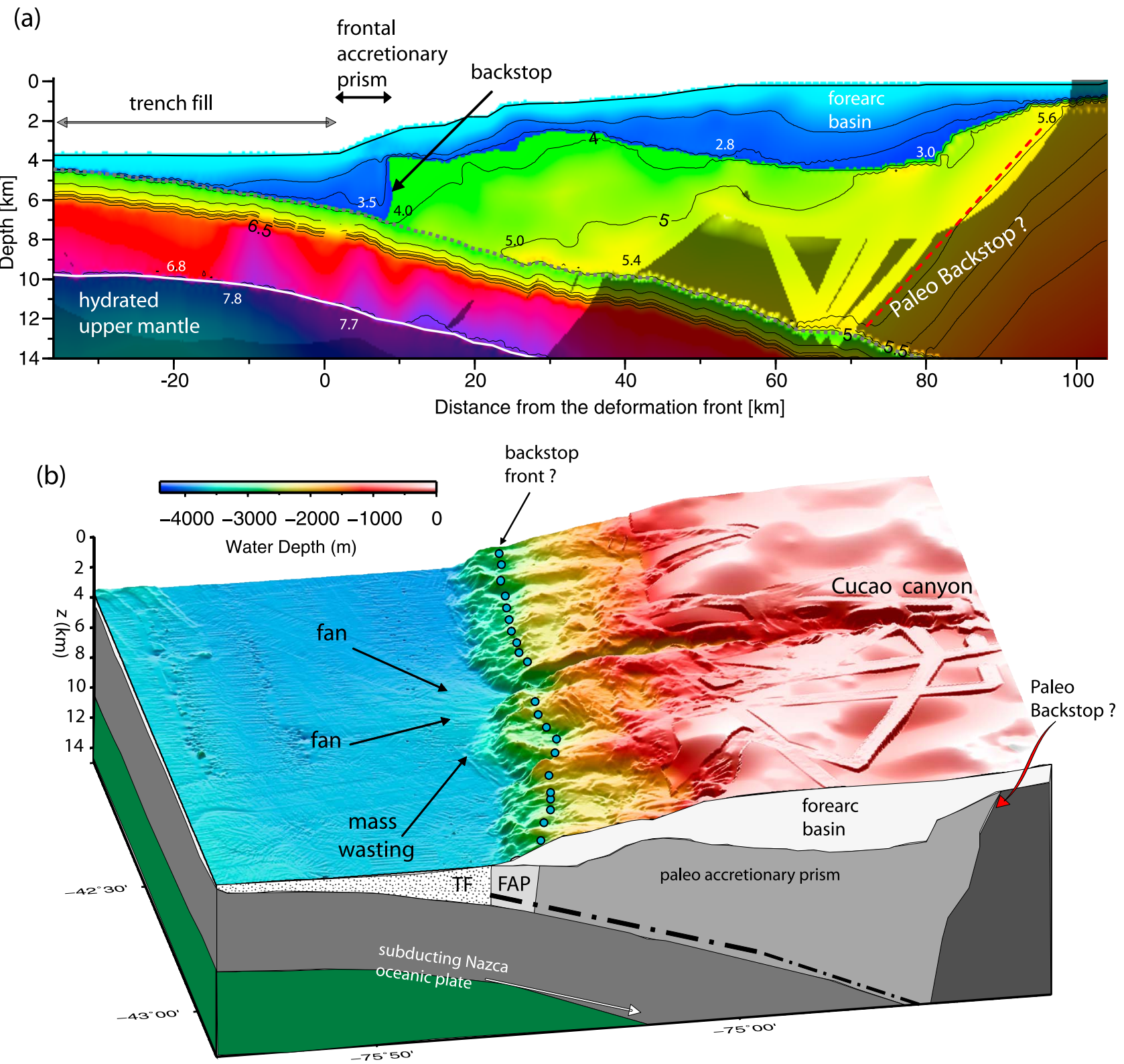

Figure 8. (a) Detailed tomographic image of the marine forearc complex off Isla de Chiloé, showing the seismic segmentation of the margin. (b) Interpretation based on the detailed tomogaphic model (see section 5.1 for details). The Cucao canyon is characterized by a deep incision left by turbidite currents and it is related to the Cucao lake that drains the Coastal Cordillera. Below the mouth of the Cucao canyon, a large sediment fan is formed and the trench is heavily sedimented. Turbidites span up to $\sim 250 \mathrm{~km}$ seaward of the trench and smooth the seafloor for a broad region [Contreras-Reyes et al., 2007]. The backstop location imaged from the seismic velocity model appears to coincide with the lower-middle slope transition. Mass wasting processes are also evident along the abrupt continental slope. Dotted line represents the subduction channel, and TF denotes the trench fill.

$>6.5 \mathrm{~km} / \mathrm{s}$ favors a rapid change in rock type (Figure $8 \mathrm{~b}$ ) and, hence, alternation between accretion and erosional phases. The size of the paleoaccretionary prism should have been much larger at the end of the accretion phase, when the complex was formed.Thereafter, an integral part of the paleoaccretionary prism was tectonically eroded [Mordojovich, 1981; Melnick and Echtler, 2006; Encinas et al., 2008]. At present, the width of $\sim 90 \mathrm{~km}$ of the paleoaccretionary prism represents the remaining material left after the last erosional phase, which took place in the Miocene according to Melnick and Echtler [2006] and Kukowski and Oncken [2006]. It is worth noting that erosion and accretion can be coeval; for instance, subducted high oceanic bathymetric features erode the margin's inner rock prism as adjacent sediment accretes. The presence of 
(a)
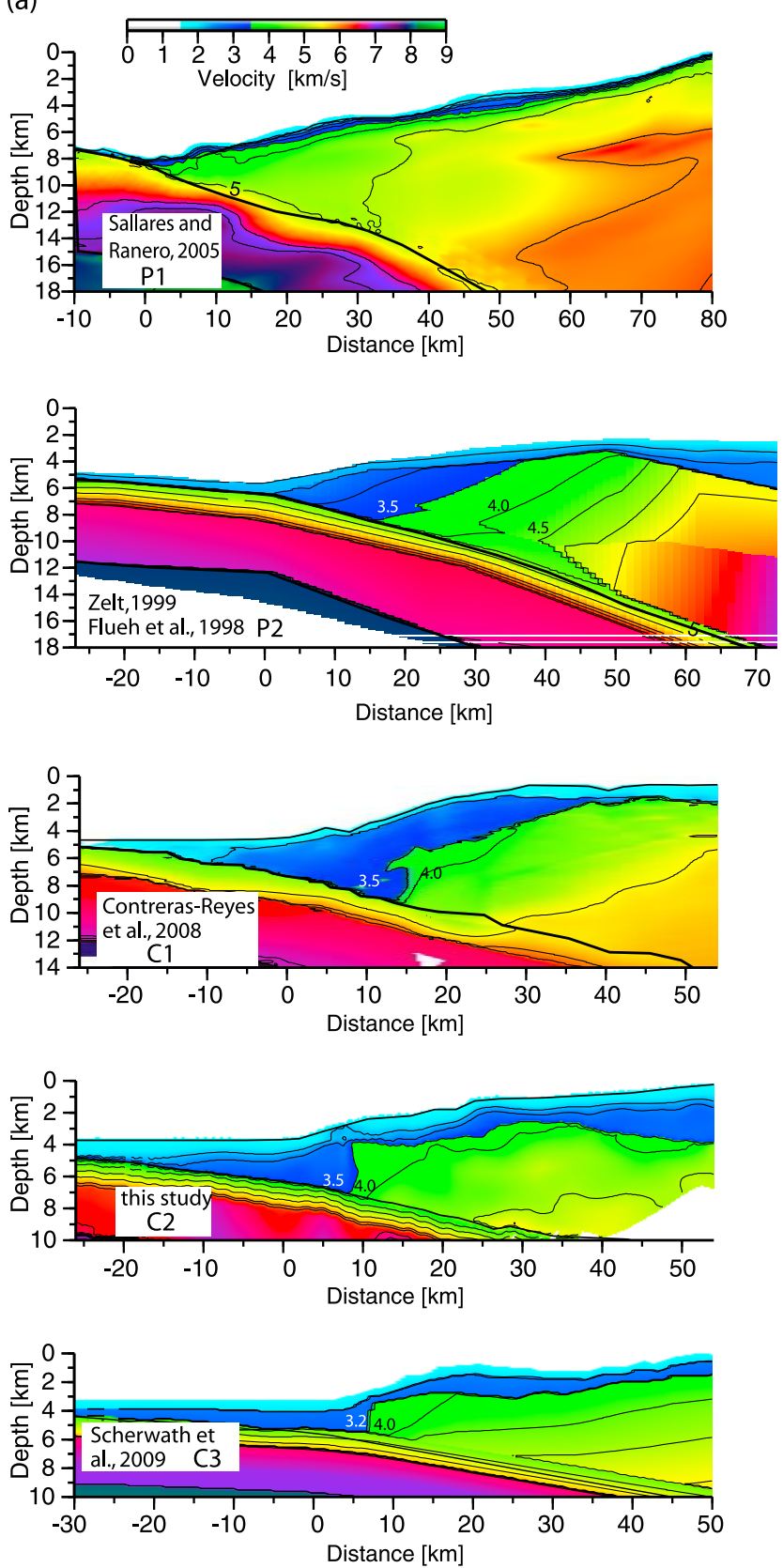

(b)
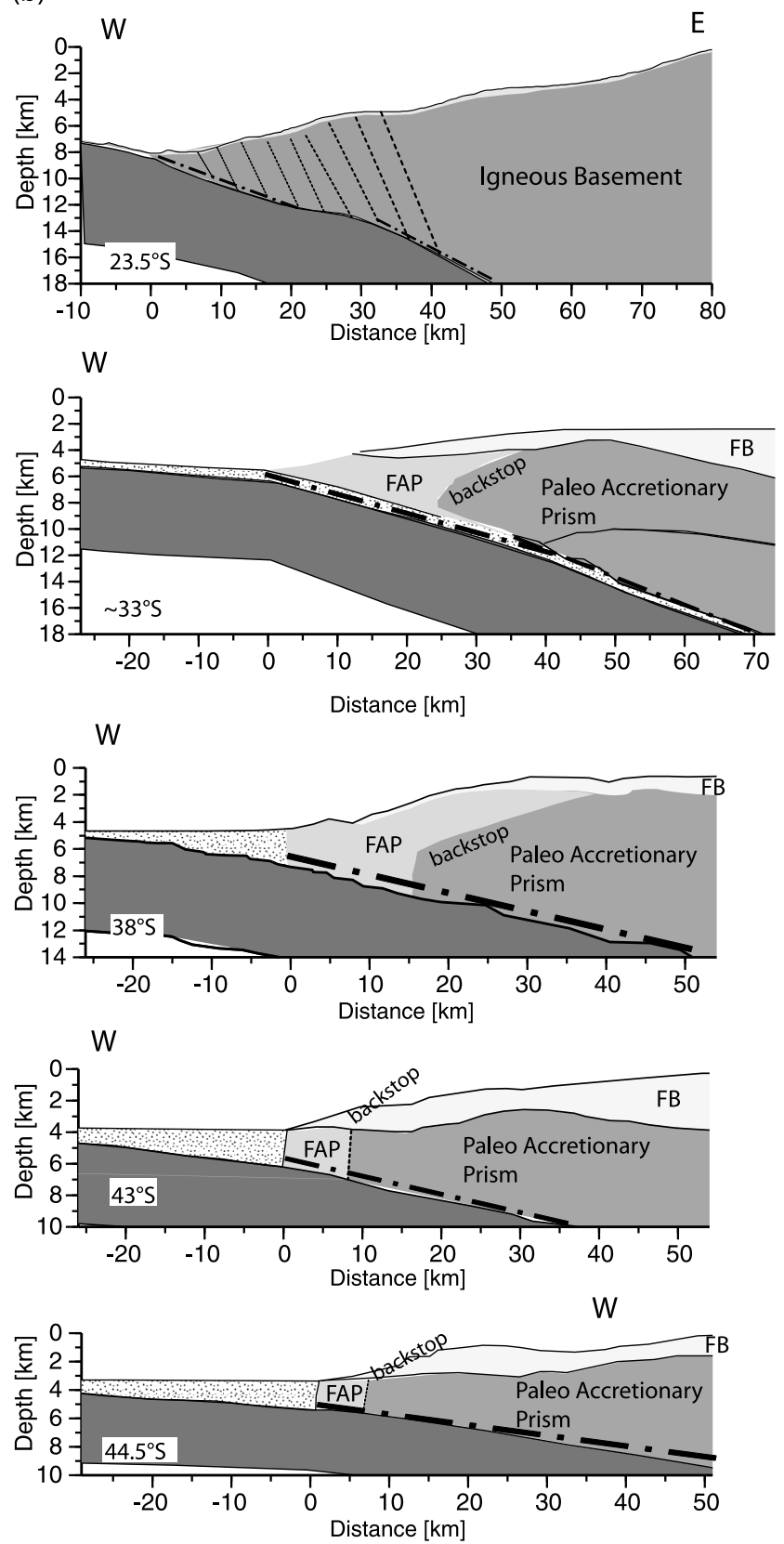

Figure 9. (a) Direct comparison of the velocity depth models between profiles P1, P2, C1, C2, and C3 and (b) their interpretation. Frontal accretionary prism velocities are based on typical sedimentary velocities in the range of 1.8 and $\leq 3.5 \mathrm{~km} / \mathrm{s}$, while the paleoaccretionary prism is based on velocities in the range of $\geq 4.0$ and $5.5 \mathrm{~km} / \mathrm{s}$. The northern erosional margin (P1) is composed mainly by metamorphic igenous rocks that have undergone a hydrofracturing process [Sallares and Ranero, 2005]. Seismic velocities decrease progresively toward the empty sedimented trench. The seismic profile P2 is located $20 \mathrm{~km}$ south of the JFR that acts to segment the Chile margin from nonerosional and erosional south and north of it, respectively [von Huene et al., 1997].

the thick Chiloé fore-arc basin above paleoaccretionary prism suggests at least some short-term episodes of basal erosion [Wells et al., 2003]. Over the long term, the SC Chilean continental margin has not been a site of net growth but rather a site of continental mass wasting, crustal recycling, and crustal rejuvenation [Glodny et al., 2006].
[29] The oceanic lithosphere is characterized by relatively low seismic velocities, suggesting that the structures of both the oceanic crust and uppermost mantle have been altered in the outer rise region, possibly due to a certain degree of fracturing and hydration. The seismic structure of the 
incoming oceanic plate is extensively discussed by Contreras-Reyes et al. [2007] and Scherwath et al. [2009].

\subsection{Characterization of the Frontal Accretionary Prism off South Central Chile}

[30] Melnick and Echtler [2006] argued that the Glacial age trench fill and the steady decrease of the subduction rate of the incoming oceanic Nazca plate from 8.5 to $6.6 \mathrm{~cm} / \mathrm{a}$ [Somoza, 1998; Angermann et al., 1999] had shifted the margin from erosive to accretionary during the Pliocene (5-6 Ma). The exhumation of Miocene granitoids [Seifert et al., 2005] and fission track dating in the main Cordillera [Glodny et al., 2006] show that denudation rates have increased substantially since about $5 \mathrm{Ma}$, which was approximately the time of the onset of Southern Hemisphere glaciation [Rabassa and Clapperton, 1990]. Kukowski and Oncken [2006] studied temporal variation of the trench fill thickness over the past $25 \mathrm{Ma}$, taking into account several factors such as pelagic sediment input, volume of eroded material from the Andean and Coastal Cordillera, debris sourced by mass wasting along the continental slope, material loss from the accretionary prism due to subduction erosion, thickness of sediment trapped in the fore-arc basin, mass flux from the erosion of volcanoes, and an age porosity of $30 \%$ for the clastic sediment. Their results show a moderate trench fill of between 0.5 and $1.0 \mathrm{~km}$ during the Miocene and a strong increase to $\sim 2 \mathrm{~km}$ thickness since 5-6 Ma, which is the present-day average value. The fast increase of glacial sediment flux during the Pliocene has facilitated the formation of a FAP [Kukowski and Oncken, 2006]. It is worth mentioning that the SC Chile margin over the long term (i.e., the past several hundred million years) should be considered as an erosional margin. This explains the close proximity of continental crust to the modern trench and small size of the FAP. If the SC Chile margin is viewed since the late Cenozoic glaciation flooded the trench axis with sediment, however, the margin can be classified as accretionary in the sense that the growth of an FAP has expanded the width of the margins seaward with respect to a fixed position on the continental plate.

[31] The frontal accretionary prism formed since the Pliocene shows structural diversity along the SC Chile margin. Figure 9 shows a compilation of 2-D velocity models along the Chile margin displaying the main structural differences in terms of seismic velocities. Wedged-shaped bodies with typical sedimentary velocities of $<4.0 \mathrm{~km} / \mathrm{s}$ are commonly attributed to the FAP, as is illustrated in Figure 9b. We attempt to compare the size of the FAP off SC Chile at different latitudes using published seismic refraction models regardless of the seismic method employed (either tomography or ray-tracing approaches). The location of the backstop is expected to be detected by both methods as is the case along corridor 2 (see section 4.5). A characterization and tectonic interpretation of the SC Chile margin is discussed in the following subsections.

\subsubsection{Tectonic Erosion Versus Accretion}

[32] Sallares and Ranero [2005] pointed out that the overriding plate in northern Chile (north of the JFR) is mainly made of arc-type igneous basement, where the front of the margin is probably fluid-saturated, metamorphosed, and disaggregated by fracturing as a consequence of frontal subduction erosion. The trench is sediment starved, the margin has no fore-arc basin, and the extensional regime across the continental slope has caused gravitational destabilization of the margin framework resulting in steepening of the margin related to progressive subduction erosion [von Huene and Ranero, 2003]. South of the JFR and north of the CTJ, in contrast, the trench is shallower and filled with thick sediment (1.5-2.5 km), and the margin presents a backstop region and has a well-developed fore-arc basin (Figure 9).

[33] A clear difference between these margins is the velocity structure at the front of the margin wedge. The frontal accretionary prism seaward of the shelf break off SC Chile has seismic velocities lower than $3.5 \mathrm{~km} / \mathrm{s}$, while off northern Chile velocities are faster than $4.0 \mathrm{~km} / \mathrm{s}$ (Figure 9). This observation suggests that the front of the SC Chile margin is composed of sediment, indicating frontal accretionary processes. Off northern Chile, in contrast, velocities $>4.0 \mathrm{~km} / \mathrm{s}$ are characteristic of igneous rocks rather than sedimentary rocks [Sallares and Ranero, 2005]. Velocities seaward of the backstop are $>4.0 \mathrm{~km} / \mathrm{s}$ (off SC Chile) and hence similar to the metamorphosed igneous continental crust off northern Chile. Metasedimentary and metamorphosed rocks are therefore indistinguishable in terms of seismic velocities. Nevertheless, the seismic velocity models for the "accretionary" SC Chile margin suggest a clear seismic segmentation, supporting episodes of accretion and erosion as we discussed in section 5.1. In contrast, at the erosional northern Chilean margin, fracturing, alteration, and erosion have continuously lowered the velocity to the seaward edge of the margin, providing a gradual change of seismic velocity within the margin wedge.

[34] The profile P2 is located $\sim 30 \mathrm{~km}$ south of the JFR, which is a region already influenced by the proximity of the JFR. A very high subsidence rate has been associated with tectonic erosion at the base of the accretionary prism in the zone of pre- and current collision of the JFR with the margin [Laursen et al., 2002]. According to the kinematic model describing the collision of the JFR with the margin of Yánez et al. [2001], the first collision occurred $22 \mathrm{Ma}$ at $\sim 20^{\circ} \mathrm{S}$ and it continued migrating southward, up to Valparaíso, $10 \mathrm{Ma}$. Thereafter, the area of collision remains stationary at this latitude until the present. Likely, intense frontal and basal subduction erosion linked to the collision of the JFR have caused the landward trench migration seen in bathymetric maps (Figure 1) [von Huene et al., 1997; Yáñez et al., 2001; Laursen et al., 2002]. In addition, the collision of the JFR has likely accelerated erosion in the precollision zone $\left(20^{\circ}-33^{\circ} \mathrm{S}\right)$.

[35] In the current collision zone, the high relief of the JFR had reduced the sedimentation rate, which has resulted in a thinner trench fill of about $1 \mathrm{~km}$ against the average thickness of $2 \mathrm{~km}$ between the JFR and CTJ. Nevertheless, the seismic refraction data images a FAP $\sim 30 \mathrm{~km}$ wide [Flueh et al., 1998; Zelt, 1999] that has obviously not been eroded by the JFR. South of Valparaíso, tectonic erosion ceased $\sim 5 \mathrm{Myr}$ ago. The seaward trench migration south of the JFR (Figure 2) reveals that frontal accretion processes have facilitated the formation of a FAP $20-30 \mathrm{~km}$ wide (Figures 2 and 9). Off Constitución $\left(\sim 35^{\circ} \mathrm{S}\right)$ unpublished high-resolution seismic refraction data reveal an FAP up to 
Table 2. For Profiles P1, P2, C1, C2, C3, and C4 the Sediment Accreted Areas Were Estimated From Seismic Wide Lines Whereas for Profiles E1, E2, E4 and E6 the Sediment Accreted Areas Were Inferred From Seismic Reflection Lines $^{\mathrm{a}}$

\begin{tabular}{|c|c|c|c|c|c|}
\hline Profile & $\begin{array}{l}\text { Approximated } \\
\text { Latitude }\end{array}$ & $\begin{array}{c}\text { Trench Fill } \\
\text { Thickness }(\mathrm{km})\end{array}$ & $\begin{array}{c}\text { Frontal Accretionary } \\
\text { Prism Area }\left(\mathrm{km}^{3} / \text { trench-km) }\right.\end{array}$ & $\begin{array}{l}\text { Subduction Channel } \\
\text { Thickness }^{\mathrm{b}}(\mathrm{km})\end{array}$ & Reference \\
\hline P1 & $23.5^{\circ} \mathrm{S}$ & 0.1 & $\leq 5$ & $0.2 \pm 0.1$ & von Huene and Ranero [2003] \\
\hline $\mathrm{P} 2$ & $33^{\circ} \mathrm{S}$ & 1.8 & 72 & $0.9 \pm 0.1$ & $\begin{array}{c}\text { von Huene et al. }[1997] ; \\
\text { Zelt [1999] }\end{array}$ \\
\hline E1 & $35.5^{\circ} \mathrm{S}$ & 2.0 & 103 & $1.0 \pm 0.1$ & $\begin{array}{l}\text { Diaz-Naveas [1999]; } \\
\text { Grevemeyer et al. [2003] }\end{array}$ \\
\hline E2 & $36.5^{\circ} \mathrm{S}$ & 2.0 & 121 & $1.0 \pm 0.1$ & $\begin{array}{l}\text { Diaz-Naveas [1999]; } \\
\text { Grevemeyer et al. [2003] }\end{array}$ \\
\hline E4 & $37.8^{\circ} \mathrm{S}$ & 2.2 & 97 & $0.5 \pm 0.1$ & $\begin{array}{l}\text { Diaz-Naveas [1999]; } \\
\text { Grevemeyer et al. [2003] }\end{array}$ \\
\hline $\mathrm{C} 1$ & $38.2^{\circ} \mathrm{S}$ & 2.2 & 100 & $0.5 \pm 0.1$ & Contreras-Reyes et al. [2008] \\
\hline E6 & $39^{\circ} \mathrm{S}$ & 1.6 & 122 & $1.2 \pm 0.1$ & $\begin{array}{c}\text { Diaz-Naveas [1999]; } \\
\text { Grevemeyer et al. [2003] }\end{array}$ \\
\hline $\mathrm{C} 2$ & $43^{\circ} \mathrm{S}$ & 2.4 & 23 & $1.4-1.6^{\mathrm{c}}$ & this work \\
\hline $\mathrm{C} 3$ & $44.5^{\circ} \mathrm{S}$ & 2.0 & 15 & $1.8 \pm 0.25$ & Scherwath et al. [2009] \\
\hline $\mathrm{C} 4$ & $45.5^{\circ} \mathrm{S}$ & 1.5 & 13 & $1.2 \pm 0.1$ & Scherwath et al. [2009] \\
\hline
\end{tabular}

${ }^{a}$ Subduction channel thicknesses were taken from coincident reflection seismic lines (the first $10-15 \mathrm{~km}$ ).

${ }^{\mathrm{b}}$ Average thicknesses and standard deviations are calculated from the portion of subduction channel observed along the seismic reflection lines.

${ }^{\mathrm{c}}$ Subduction channel thickness along C2 are inferred from the location of the proto-decollement (Figure 10) and the size of the imaged frontal accretionary prism (Figure 5).

$40 \mathrm{~km}$ wide [Moscoso, personal communication], and off the southern Peninsula de Arauco the FAP is $20-25 \mathrm{~km}$ wide (Corridor C1, Figure 9). Corridor 1 intersects the incoming Mocha FZ roughly at the trench (Figure 2b). Thus, we can speculate that frontal and basal erosion processes linked to the subduction of Mocha FZ may remove some material of the FAP. However, the outcropping basement features associated to the Mocha FZ are mostly buried by thick turbidities [Völker et al., 2006] and the erosional effects of the Mocha FZ are therefore expected to be relatively small (at least from the Pliocene).

5.2.2. Sediment Accretion Versus Sediment Subduction

[36] The size of the FAP imaged in lines P2, C1, C2, and $\mathrm{C} 4$ are shown in Table 2, which are based on the wedge-shaped bodies with typical sedimentary velocities of $\leq 3.5 \mathrm{~km} / \mathrm{s}$ imaged seaward of the active backstop. The FAP imaged along $\mathrm{P} 2$ and $\mathrm{C} 1$ is about 5 times larger than off Isla de Chiloé and Aysén Region at $\sim 44.5^{\circ} \mathrm{S}$ (C2 and C3, respectively). This finding is surprising because the region off Isla de Chiloé and Aysén has been more affected by glacial denudation of the Austral Andes and hence the sediment input is larger. Even though a large amount of sediment accumulated in the trench south of the JFR and north of $\sim 39^{\circ} \mathrm{S}$ provided by the glaciated drainages to the south, the average sediment input is smaller than south of $\sim 39^{\circ} \mathrm{S}$ [Thornburg et al., 1990]. Therefore, the small size of the FAP along $\mathrm{C} 2$ and $\mathrm{C} 3$ suggests effective sediment subduction rather than sediment accretion to the toe of the margin.

[37] Similarly, Diaz-Naveas [1999], based on highquality seismic reflection data acquired between $35^{\circ}$ and $40^{\circ} \mathrm{S}$, concluded that north of the Mocha FZ a major portion of the trench fill is frontally accreted and the rest is underthrust beneath the decollement. In contrast, south of the Mocha FZ a very thin layer $(300 \mathrm{~m})$ is frontally offscraped, and all the remaining trench fill is further subducted. This work already showed diversity of the process of offscraping, underplating, and subduction of sediment as well as a transition zone around Mocha FZ from effective accretion to effective subduction of sediment (see section 5.3.2 for further discussion). Our new findings extends the region characterized by effective sediment subduction further south (up to $\sim 45^{\circ} \mathrm{S}$ ).

[38] We also include in Table 2 the size of the FAP observed along the seismic reflection lines of Diaz-Naveas [1999] and Grevemeyer et al. [2003]. The information shown in Table 2 shows two main domains along the SC Chile margin: (1) South of the JFR and north of $39^{\circ} \mathrm{S}$ the accreted portion of sediment is larger $\left(70-120 \mathrm{~km}^{3} /\right.$ trench-km) and (2) south of $39^{\circ} \mathrm{S}$ and north of the CTJ the FAP size is considerably smaller $\left(15-25 \mathrm{~km}^{3} /\right.$ trench-km). Between $38^{\circ} \mathrm{S}$ and $40^{\circ} \mathrm{S}$, the Chile trench and the Mocha and Valdivia fracture zones define the Mocha block (MB), which appears to be a transition zone regarding the sediment accreation/subduction mode. The MB separates effective sediment accretion in the north from effective sediment subduction in the south. Hereafter, we refer to the Maule segment as the region south of the JFR and north of the MB, which is a region characterized by a relatively large FAP, and the Chiloé segment as the region south of the MB and north of the CTJ, which is a region characterized by a relatively small FAP.

[39] The volume of accreted sediment per $\mathrm{km}$ of margin, $A$, with an age, $T$, can be computed as a function of variations of sediment supply (that is, in the trench-axis sediment thickness $h$ multiplied by subduction speed $V$ and corrected for compaction $\kappa$ ) as follows:

$$
A=\int_{0}^{T} h(t) \kappa V d t
$$

[40] The sedimentary thickness at the trench axis depends on the sedimentation rate and hence time $t$. Similarly $V$ and $\kappa$ can vary with time. For simplicity, we take the average values 
of $V, h$, and $\kappa$ to approximate the age of the frontal accretionary prism $T$ to the following:

$$
T \approx \frac{A}{h \kappa V} .
$$

[41] From the prism volumes observed in Table 2 and (2), it becomes evident that the existing wedges may have been built during a short time spanning only $\sim 0.2-1.5$ million years. For example, along E6 and $\mathrm{C} 3$ the age of the frontal accreted prism should be $\sim 1.47 \mathrm{Ma}$ and $\sim 0.18 \mathrm{Ma}$, respectively (using $\kappa=0.7$ and $V=66 \mathrm{~km} / \mathrm{Ma}$ and the respective trench fill thickness for each seismic section shown in Table 2). This is a considerably shorter amount of time than since the onset of glaciation with its associated high sediment flux (5-6 Ma). Thus, the portion of the trench fill accreted to the toe of the margin must have grown over time to the present-day value, while the amount of subducted and underplated material must have decreased [Kukowski and Oncken, 2006].

\subsection{Subduction of Sediments: Subduction Channel}

\subsubsection{Seismic Properties of the Subduction Channel}

[42] Subduction of poorly consolidated sediment (subduction channel) beneath the overriding accretionary prism and crystalline or paleoaccretionary block are usually assumed to be characterized by lower seismic velocities than the overriding structures and thus may form a low velocity zone (velocity inversion). Diaz-Naveas [1999] used depthmigrated multichannel seismic reflection data to yield a $\sim 1 \mathrm{~km}$ thick layer of subducting sediment above the top of the downgoing plate along profile E6. The velocity contrast between the overlying prism and subducted sediments was rather small $(<0.2 \mathrm{~km} / \mathrm{s})$, roughly comparable with the velocity uncertainties of our tomographic model (Figure $5 \mathrm{~d}$ ). Using the high resolution of our refraction data, we test several initial models, including a low-velocity zone beneath the paleoaccretionary prism with velocities of poorly consolidated sediment $(<4.0 \mathrm{~km} / \mathrm{s})$ as have been proposed by several authors [Flueh et al., 1998; Sage et al., 2006; Calahorrano et al., 2008]. After several changes of the thickness and velocity gradient of the low-velocity layer we came to the conclusion that our best model favors a more gradual velocity structure above the plate boundary and hence could not resolve a subduction channel.

[43] Bangs and Westbrook [1991] used synthetic seismograms to model the waveform of the decollement of the Barbados Ridge accretionary complex. They used different values for the thickness and velocity contrast of a low velocity zone beneath the prominent decollement reflector. Their best model consists of a thin, $20 \mathrm{~m}$ thick, low-velocity layer at the decollement horizon with a relative velocity decrease in the layer of $0.2 \mathrm{~km} / \mathrm{s}$ to about $1.75 \mathrm{~km} / \mathrm{s}$. They interpreted this prominent and thin reflector in terms of a shear zone that has high porosity maintained by elevated pore fluid pressure. That is, the low-velocity zone might not have much of a contrast with the overlying material or it may be very thin and just beneath or within the plate boundary interface. Therefore, the existence of a prominent decollement reflector and hence the top of the subduction channel can be explained without the need of imposing a several-hundred-meters-thick low-velocity layer simulating the entire subduction channel. However, a recent 3-D seismic reflection study in the Nankai Trough subduction zone reported a $1-2 \mathrm{~km}$ thick underthrust low seismic impedance (presumed to be low-velocity and low-density) underneath a weakly coupled region (accretionary prism) [Bangs et al., 2009]. Thus, different cases are possible regarding infereing the thickness of the low-velocity zone of underthrusted sediment and it is not be possible to conclude what is happening in Chile based on what is seen in other settings.

[44] Figures 10, 11, and 12 show the seismic reflection data for lines C2, C3, C4, E1, E2, E4, and E6. The prominent decollement reflector is observed in most of the seismic lines. We believe that the origin of the decollement reflector with inverse polarity is due to a thin layer $(<20 \mathrm{~m})$ of low velocity and rich fluid. A thickness of $\sim 20 \mathrm{~m}$ is only $1 \%$ of the typical thickness of the subduction channel along these reflection lines. This could explain why the decollement reflector cannot be detected by seismic refraction profiles but it can be recognized from high-resolution seismic reflection data.

[45] In this context, it is noteworthy that seismic refraction data provide a good constraint on the location of the backstop region, and hence the size of the FAP, but the thickness of the subduction channel is poorly resolved. In contrast, seismic reflection data poorly image the backstop region because this is located where multiples mask the data. Even by removing the multiples, the seismic reflection data usually suffer from too little energy at greater depths. However, multichannel seismic reflection data usually image the decollement reflector and the thickness of the subduction channel rather well.

\subsubsection{Variations of the Subduction Channel's Thickness Along the Chile Margin}

[46] Seismic reflection data reveal that $20 \%$ to $80 \%$ of the current trench fill is being subducted [Diaz-Naveas, 1999; Behrmann and Kopf, 2001; Scherwath et al., 2009]. Figures 10 and 11 show the trench fill and decollement reflector for profiles $\mathrm{C} 2, \mathrm{C} 3$, and $\mathrm{C} 4$. The data quality shown in Figure 10 (C2) landward of the deformation front is rather poor. However, two clear sequences of incoming sediment can be identified: the youngest and shallow sediment are being added to the toe of the margin ( $\sim 20 \%$ of the trench fill above the proto-decollement) and the rest are entering coherently to the subduction channel. The proto-

Figure 10. (a and b) Multichannel seismic data along corridor 2 converted to depth using seismic refraction data (Figure 5). This seismic section images the arcward part of the outer rise, trench, and FAP. The formation of the subduction channel composed of thick turbidites appears to be formed several tens of kilometers seaward of the deformation front. If the location of the decollement is correct then more than $70 \%$ of the trench sediment subduct in close agreement with the extremely small FAP imaged by seismic refraction data (Figures 5-8). 

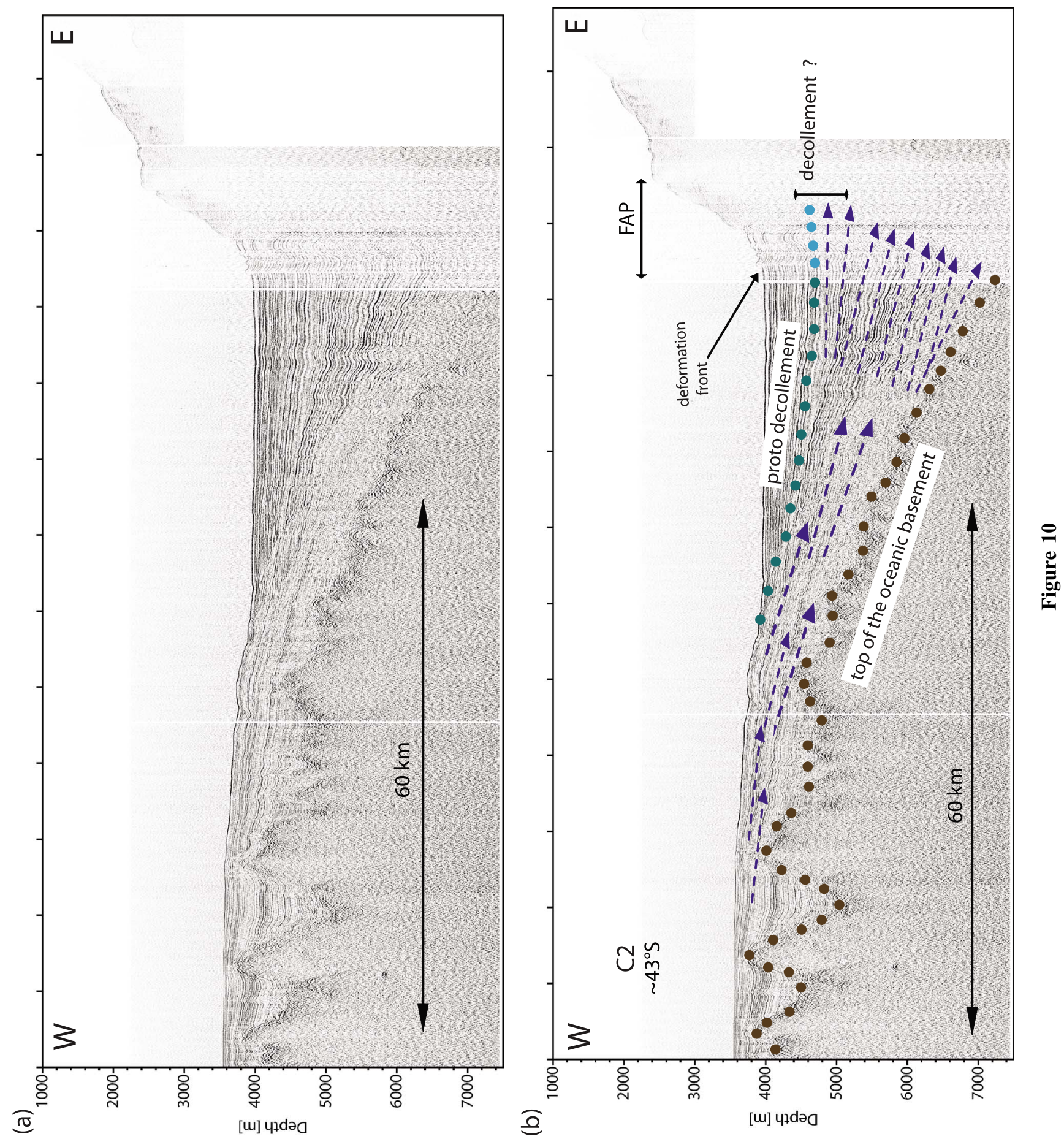

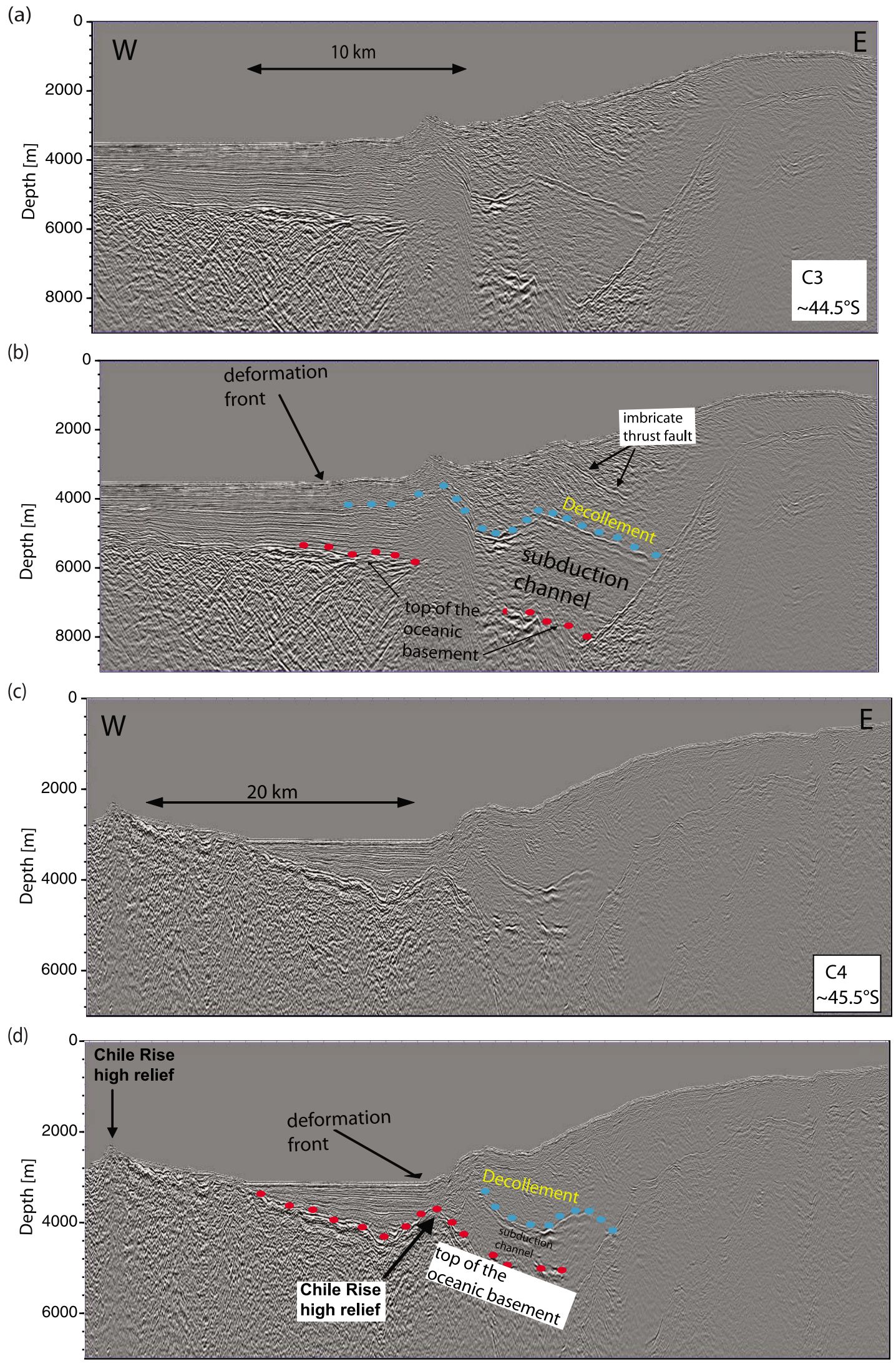

Figure 11 
decollement may correspond to a prominent reflector of turbitic flows filling the trench basin that on laps sedimentary drape covering the oceanic crust, and it appears to form a detachment. Although the interpreted location of the decollement is doubtable, a thick subduction channel can be inferred from the extremely small size of the FAP imaged from high-resolution wide-angle data (Figures 5-8). In fact, the FAP is $\sim 5$ times larger along the Maule segment than along the Chiloé segment $(<10 \mathrm{~km}$ wide), which suggests that sediment subduction is more effective along the Chiloé segment.

[47] Figure 11 shows better seismic reflection images for corridors C3 and C4, which were depth migrated by Scherwath et al. [2009]. Along C3, the decollement is clearly seen and marks the roof of the subduction channel at $1.8 \pm 0.25 \mathrm{~km}$ above the subducted oceanic basement, whereas along $\mathrm{C} 4$ the thickness of the subduction channel is $1.2 \pm 0.1 \mathrm{~km}$ thick. C4 is located only $100 \mathrm{~km}$ north of the CTJ, and it is currently an area affected by the buoyancy and high relief of the Chile Rise. In particular, corridor 3 (the closest to corridor 2, $150 \mathrm{~km}$ south of Isla de Chiloé) exhibits both well-constrained seismic reflection and refraction data, which show a thick subduction channel thickness $(1.8 \pm 0.25 \mathrm{~km}$, Figure 11$)$ and small FAP $(\sim 5 \mathrm{~km}$ wide, Figure 9), respectively. A small FAP is directly related with a thick subduction channel and vice versa (assuming a similar input of trench fill sediment, which is the case). We therefore concluded that the presence of a thick subduction channel off Isla de Chiloé is very likely.

[48] Effective sediment subduction north of the CTJ is also reported by Behrmann and Kopf [2001], who reported subduction of the trench sediment of almost $80 \%$ at $200 \mathrm{~km}$ north of the CTJ. Sediment subduction rate, however, decreases toward the CTJ as the flank of the spreading ridge approaches the trench. South of the CTJ the sediment rate increases again, though seismic profiles show that a large fraction $(>70 \%)$ of the sediment on the downgoing Antarctic plate has been scraped off and was frontally accreted to the Chile fore arc instead of subducted [Behrmann and Kopf, 2001]. Further south $\left(51^{\circ}-57^{\circ} \mathrm{S}\right)$, however, the trench fill is up to $3.7 \mathrm{~km}$ thick and more than half of the available sediments are being subducted [Polonia et al., 2007]. This region, located south of the Antarctic-Scotia-South America junction, is characterized by oblique convergence, transcurrent motion, and tectonic rotation on land. Thus, factors other than subduction rate and trench fill thickness likely affect the style of subduction accretion and nonaccretion. In contrast, between $45.5^{\circ} \mathrm{S}$ and $48^{\circ} \mathrm{S}$, seismic reflection and bathymetric data evidenced the effective formation of a large accretionary prism (60-70 km wide) where the slow convergence rate and orthogonal convergence has facilitated its formation [Behrmann and Kopf, 2001; Ranero et al., 2006].

[49] On the other hand, seismic lines E1, E2, and E4, shown in Figure 12, reveal that less than $40 \%$ of the available sediment at the trench is being subducted. Bangs and Cande [1997] and Diaz-Naveas [1999] concluded that frontal accretion predominates north of Isla Mocha $\left(\sim 38.2^{\circ} \mathrm{S}\right)$ where the decollement reflector lies near the top of the oceanic basement. Thus, the SC Chile margin can be classified as two main segments in terms of the subduction channel thickness: (1) the Maule segment (thin subduction channel of $<1.0 \mathrm{~km}$ and effective sediment accretion) and (2) the Chiloé segment (thick subduction channel of $\sim 1.5 \mathrm{~km}$ and only a small portion of the trench fill is accreated to the fore arc). Figure 13 summarizes our main findings along the Maule and Chiloé segments in terms of the subduction channel thickness and the FAP size.

\subsection{Factors Controlling the Amount of Subducted Sediment}

[50] According to Cloos and Shreve [1988], the amount of accreted or subducted sediment depends on the relation between sediment supply and the inlet capacity. If sediment supply is less than the inlet capacity, then all incoming sediment is subducted, whereas if sediment supply exceeds inlet capacity, then some of the arriving sediment is offscraped at the inlet, some is underplated near it and generally also farther arcward, and the rest is subducted [Cloos and Shreve, 1988]. Variations in sediment supply depend, in turn, on the amount of sediment deposited at trench axis and subduction speed. Clift and Vannucchi [2004] claimed that tectonic accretion occurs preferentially in margins with abundance of sediment at the trench $(>1 \mathrm{~km}$ thick) and when the subduction rate is rather slow $(<7.0 \mathrm{~cm} / \mathrm{a})$, giving enough time for the accumulation of sediment at the toe of the overriding plate. In contrast, sediment subduction occurs in margins with a rapid convergence rate able to transport thick sediment on top of the downgoing plate to great depths [von Huene and Ranero, 2009]. This could explain the presence of a thick subduction channel in the Chiloé segment where the oceanic Nazca plate subducts at a relatively fast rate, whereas south of the CTJ the slow convergence $(\sim 1.9 \mathrm{~cm} / \mathrm{a})$ of the oceanic Antarctic plate has facilitated the formation of large accretionary prisms. However, the subduction rate does not explain the change from accretion to nonaccretion modes between the CTJ and JFR explained previously, because the convergence rate between the Nazca and South American plates is obviously the same along this segment (Figure 2a).

Figure 11. ( $a$ and b) Multichannel seismic data from RC 2901 Line 734 from Lamont-Doherty Earth Observatory cruise in 1988 using RV CONRAD, converted to depth using seismic refraction data along profile C3 by Scherwath et al. [2009]. Light blue dots denote the interpreted decollement reflection below which sediment are subducting within the subduction channel whereas above the decollement active sediment accreation takes place. Note that less than $30 \%$ of the trench fill is accreated above the decollement. (c and d) Multichannel seismic data from RC 2901 Line 743, converted to depth using the velocity model of corridor 4 [Scherwath et al., 2009]. A major part of the trench fill subduct, though, the high relief of the near Chile Rise appears to displace turbidites at the deformation front resulting in a decrease of both accreted and subducted sediment. 
(a)
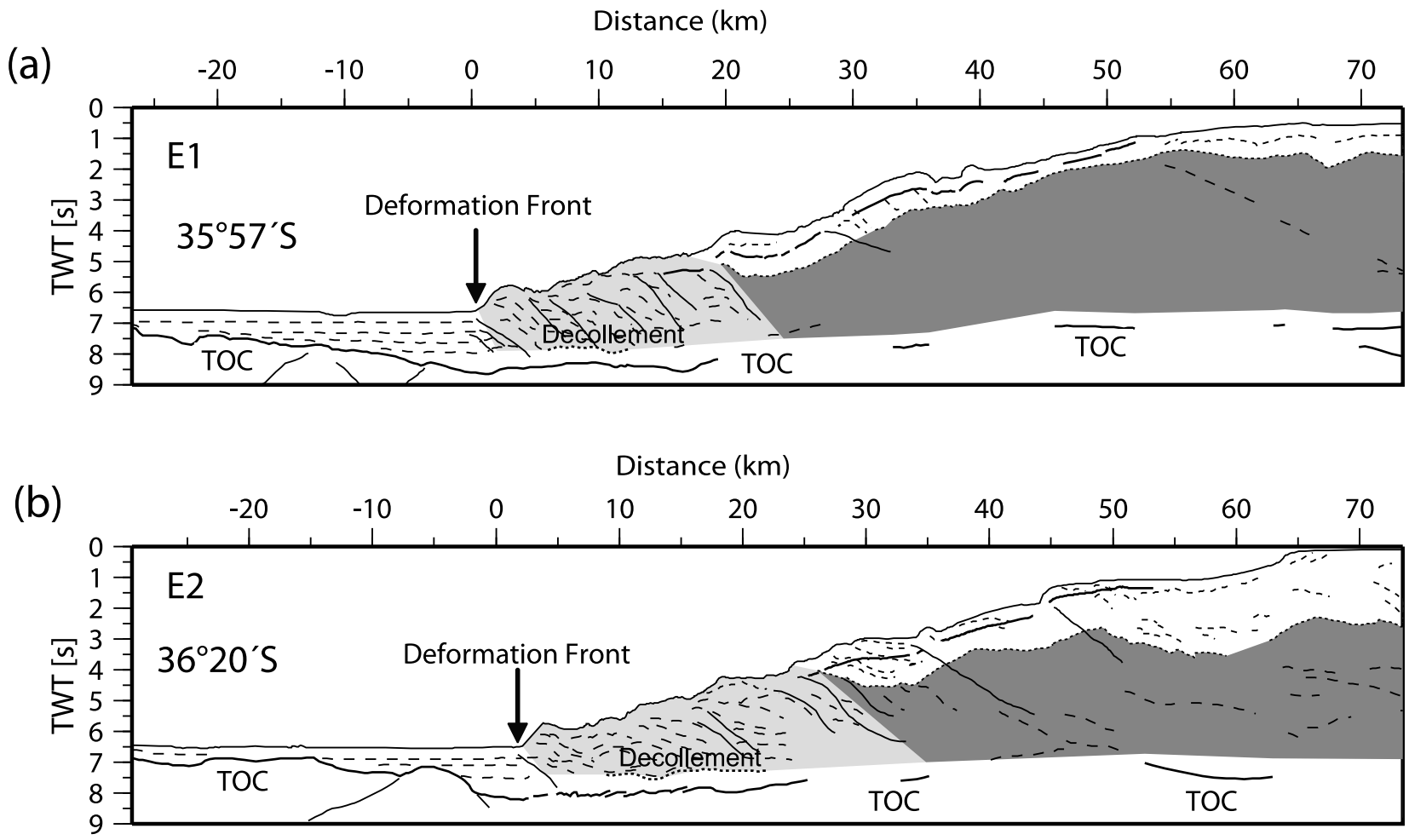

Distance (km)

(c)

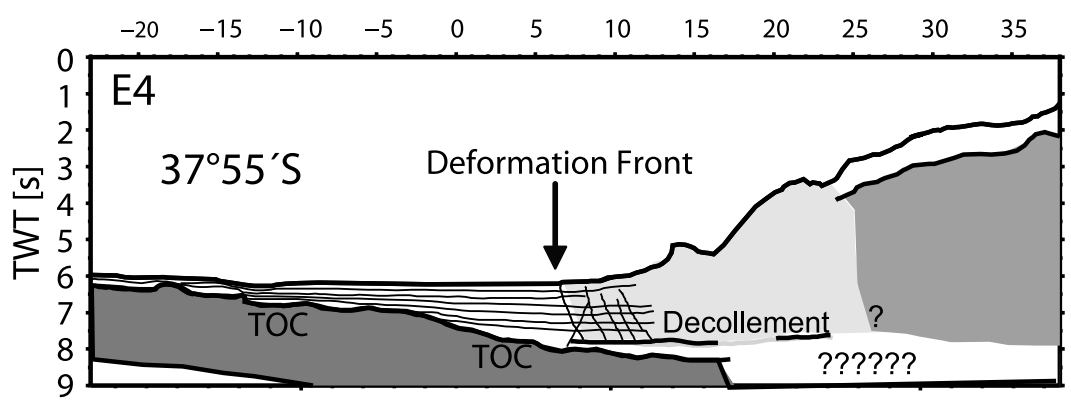

(d)

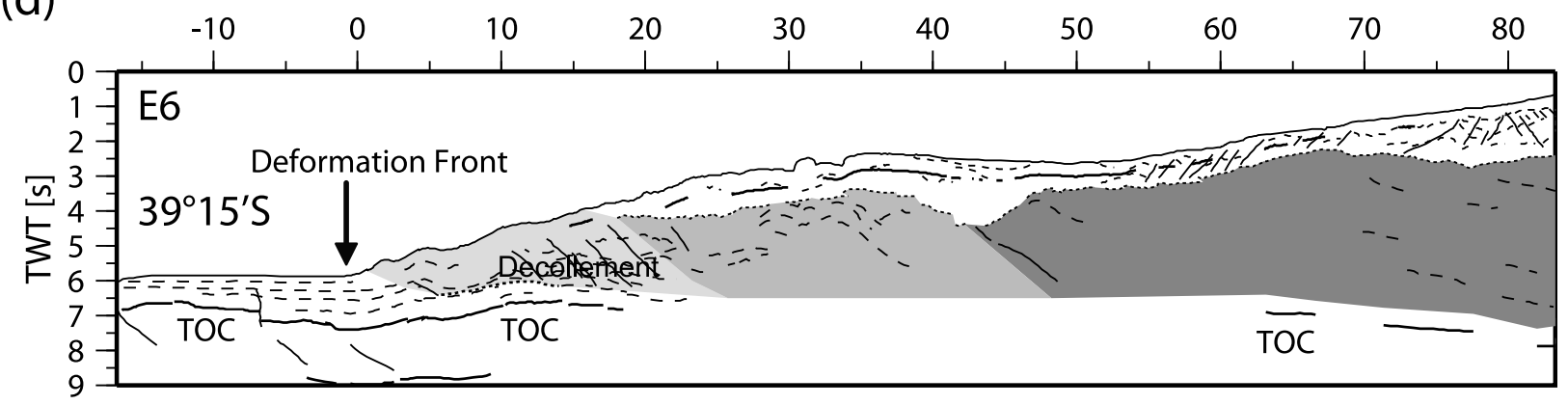

Figure 12. Interpretation of final stack and finite difference poststack time migration for lines E1, E2, E4, and E6 (taken from Diaz-Naveas [1999] and Grevemeyer et al. [2003]). 


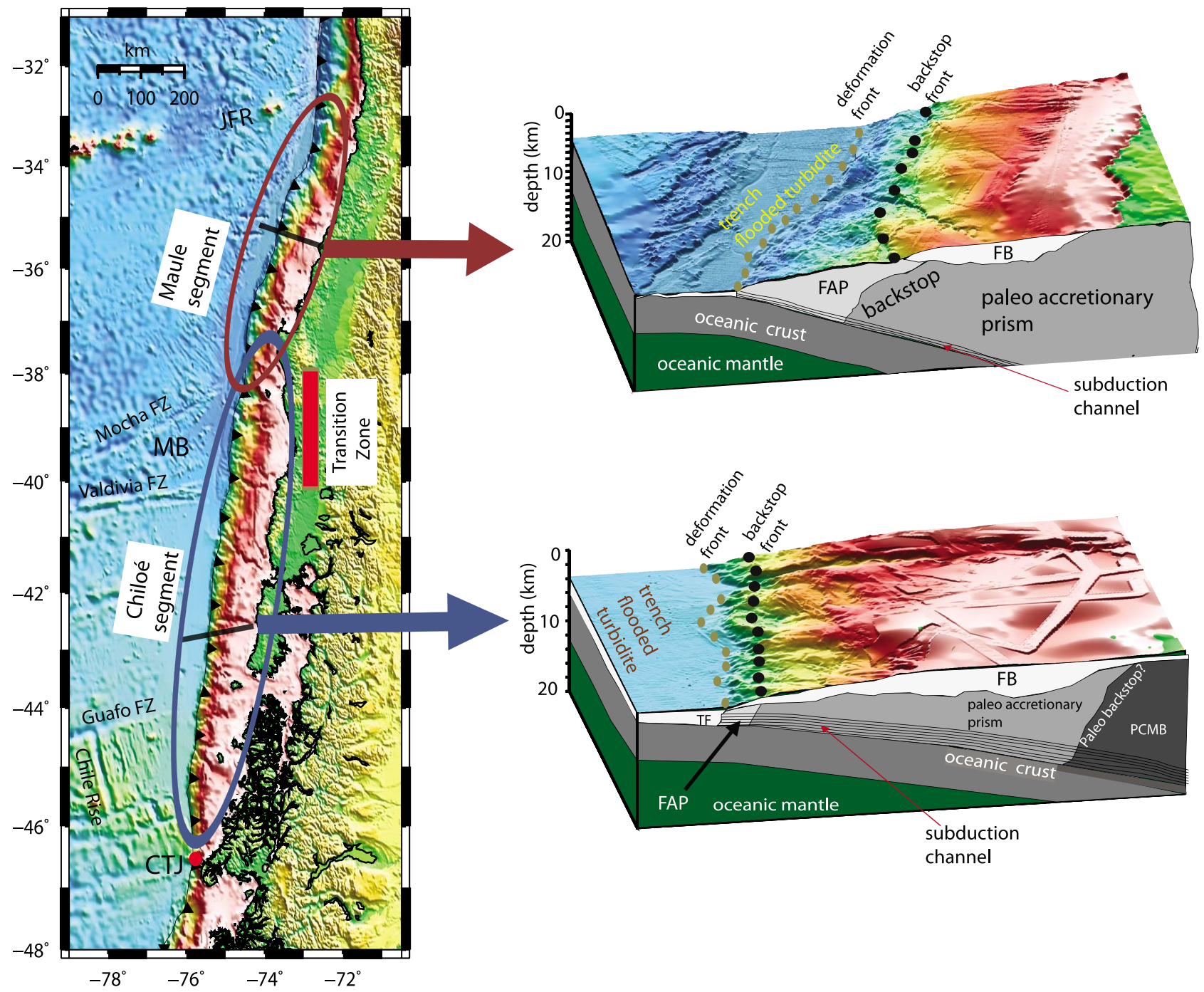

Figure 13. The Chilean marine forearc can be defined by two main tectonic segments separated by the Mocha block (MB) that defines a transition zone and is composed of the triangulation of the Valdivia FZ system, Mocha FZ, and the Chile trench. The Mocha block defines a transitional change of thermal properties of the oceanic lithosphere and it separates young ( $0-25 \mathrm{Ma})$ and old ( $>30-35 \mathrm{Ma})$ oceanic lithosphere south and north of it, respectively. The northern segment is referred as the Maule segment and is located south of the Juan Fernández Ridge and north of the MB. This segment is characterized by subduction of relative cold and rigid oceanic lithosphere and the margin has a relative wide FAP $(20-40 \mathrm{~km}$ wide) and a thin subduction channel $(<1 \mathrm{~km}$ thick). The southern segment is referred as the Chiloé segment located south of the MB and north of the CTJ. This segment is characterized by subduction of young and hot oceanic lithosphere and the margin has a small FAP $(<10 \mathrm{~km}$ wide $)$ and a thin subduction channel $(\sim 1.5 \mathrm{~km}$ thick).

[51] The initial angle of subduction plays a crucial role in determining the inlet capacity and hence the amount of subducted or accreted sediment [e.g., Jarrard, 1986]. Subduction angle beneath the submerged fore arc is generally small where a wide ridge or thick crustal block enters the subduction zone. Where this happens, characteristically the rate of frontal and basal subduction erosion is enhanced, older accreted and basement material is stripped from the margin, and sediment subduction is favored, for example, at the CTJ. However, there is no evidence for any ridge col- lision during the Cenozoic south of the JFR and north of the CTJ.

[52] The initial angle of subduction is also and mainly influenced by the thermal age in the manner that the buoyancy of young and hot plates cause a shallow initial angle of subduction and hence more sediment would be accreted. However, we see exactly the opposite off SC Chile, where the subduction channel's thickness is greater where the oceanic Nazca plate is younger along the Chiloé segment (5-25 Ma) and thinner where the Nazca plate is 
older along the Maule segment (30-38 Ma). We propose that the initial angle of subduction would also be influenced by sediment loading that deflects the lithosphere downward in the vicinity of the trench axis and hence increases the initial angle of subduction [Contreras-Reyes and Osses, 2010]. The amount of deflection depends on the elastic properties of the plate and hence on the thermal age. Old plate is more rigid and elastic and it is able to support loading with less deformation than young and weak plate which deform more pronounced [e.g., Watts, 2001]. Thus, a large initial angle of subduction is expected to develop for young plates, whereas small initial subduction angles for old oceanic plates under thick trench sediment loading conditions.

[53] Around $39^{\circ} \mathrm{S}$, the Mocha block separates young (0$25 \mathrm{Ma}$ ) and old (30-35 Ma) oceanic lithosphere south and north of it, respectively [Tebbens et al., 1997]. This area is characterized by high stress concentration on the plate interface that acts as a main tectonic boundary separating the rigid (more elastic) plate in the north and the less elastic plate in the south. Thus, the reduced elasticity of the plate north of the CTJ and south of the MB has favored a pronounced down-deflection at the trench due to sediment loading [Contreras-Reyes and Osses, 2010], which in turn may have facilitated an increase of the initial angle of subduction and hence the formation of a thick subduction channel. Similar features were also observed off southern Patagonia $\left(51^{\circ}-55^{\circ} \mathrm{S}\right)$ where depth migrated seismic reflection sections seem to show a downflexing of the oceanic Antarctic plate beneath the sediment loaded axial region of the southern Chile trench [Polonia et al., 2007].

\subsection{Implications for Coseismic Rupture Processes of the 1960 and 2010 Megathrust Earthquakes}

5.5.1. Updip Limit of the 1960 and 2010 Earthquakes

[54] The surface area of the earthquake fault plane, together with the slip amount and frictional properties along the subduction interface control the magnitude of the earthquake. The seismogenic portion of the fault plane is bounded by an updip and downdip limit [e.g., Tichelaar and Ruff, 1993]. The updip is also referenced as the arcward limit of the aseismic/stable sliding (caused by either velocitystrengthening frictional behavior of the fault gouge or by very low normal stresses) [Scholz, 2002]. The position of the updip limit exerts a strong control on tsunami generation and is thought to occur at $100^{\circ}-150^{\circ} \mathrm{C}$ in most subduction zones [Oleskevich et al., 1999]. Alternatively, the up-limit position can be controlled by the size of the FAP, since the the plate boundary below the FAP behaves aseismically mainly due to the presence of high-porosity, fluid-rich sediment [Byrne et al., 1988]. Thus, the underconsolidated sediment forming the FAP characterized by an anomalous high-porosity could significantly deepen the updip limit of the seismogenic portion of the megasplay fault. They would lack sufficient competence to lock the fault and sustain large shear stresses; furthermore, they would exhibit velocity-strengthening behavior that would tend to terminate rupture [Wang and $\mathrm{Hu}$, 2006]. Thus, we might expect slip would terminate on the landward extension of the FAP as shown by Byrne et al.
[1988] with several examples (central Aleutians, Japan, eastern Aleutian, and Middle America subduction zones). In addition, the amplitude of the tsunami is controlled both by the amplitude of seafloor uplift/subsidence and by whether this occurs in deep or shallow water, which in turn depends on the morphology of the fore arc as well as the updip limit of the seismogenic zone.

[55] Two excellent examples to examine the impact of the backstop position (updip limit) on earthquake magnitude and tsunami amplitude are the 1960 and 2010 megathrust earthquakes whose rupture areas are confined within our study area. The geometry and structure across the coseismic rupture zone of the 2010 and 1960 earthquakes based on the seismic velocities models shown in Figure 9 are summarized in Figure 14. It is worth noting the excellent spatial correlation of the 2010 rupture area with the Maule segment and the 1960 rupture area with the Chiloé segment (Figures 2b and 13). The most striking difference between the structure of the rupture of these earthquakes is the location of the backstop relative to the deformation front (Figure 14). According to Byrne et al. [1988], the backstop defines the position of the expected updip limit of the coseismic rupture area and also marks the width of the subducting oceanic crust/accretionary prism contact zone and hence has a strong influence on the earthquake magnitude. The seismogenic zone across the 1960 rupture zone is much longer than the 2010 rupture zone (Figure 14). It seems that the FAP width is inversely proportional to the earthquake magnitude.

[56] The decollement contact surface between the FAP and subducting oceanic crust can be regarded as an aseismic region due to the low shear stress conditions along the subduction interface below the FAP [Byrne et al., 1988; Nakanishi et al., 2002]. If this is correct then the width of the aseismic region along the Maule segment is much larger than in the Chiloé segment (about 5 times wider). This difference, recognized in the seismic velocity models, suggests that the rupture process did not extend to near the trench during the Maule earthquake. Similar observations have been reported by preliminary fault slip models using GPS data of the Maule earthquake [e.g., Moreno et al., 2010], as well as the preliminary aftershock distribution [http://neic.usgs.gov]. In contrast, indications from tsunami models and joint inversions suggest that the 1960 earthquake rupture may have propagated all the way to the trench [Barrientos and Ward, 1990; Moreno et al., 2009].

[57] The relatively wide FAP along the Maule segment may have facilitated resistance to rupture propagation because too-large a proportion of the plate interface is in the stable regime. Similar processes have been reported for the Sumatra megathrust earthquake [Tilmann et al., 2010]. In contrast, the FAP along the Chiloé segment (1960 rupture area) was too small to resist trenchward rupture propagation. Thus, the rupture area of the 1960 earthquake is not only larger than the 2010 earthquake along strike but also along the dip if we assume the same depth location of the downdip limit ( 40 km) [Haberland et al., 2009].

[58] Elastic dislocation modeling following Okada [1992] shows that maximum coseismic uplift is achieved approximately above the updip end of the most intense coseismic rupture. Thus, the more seaward the updip is positioned the 


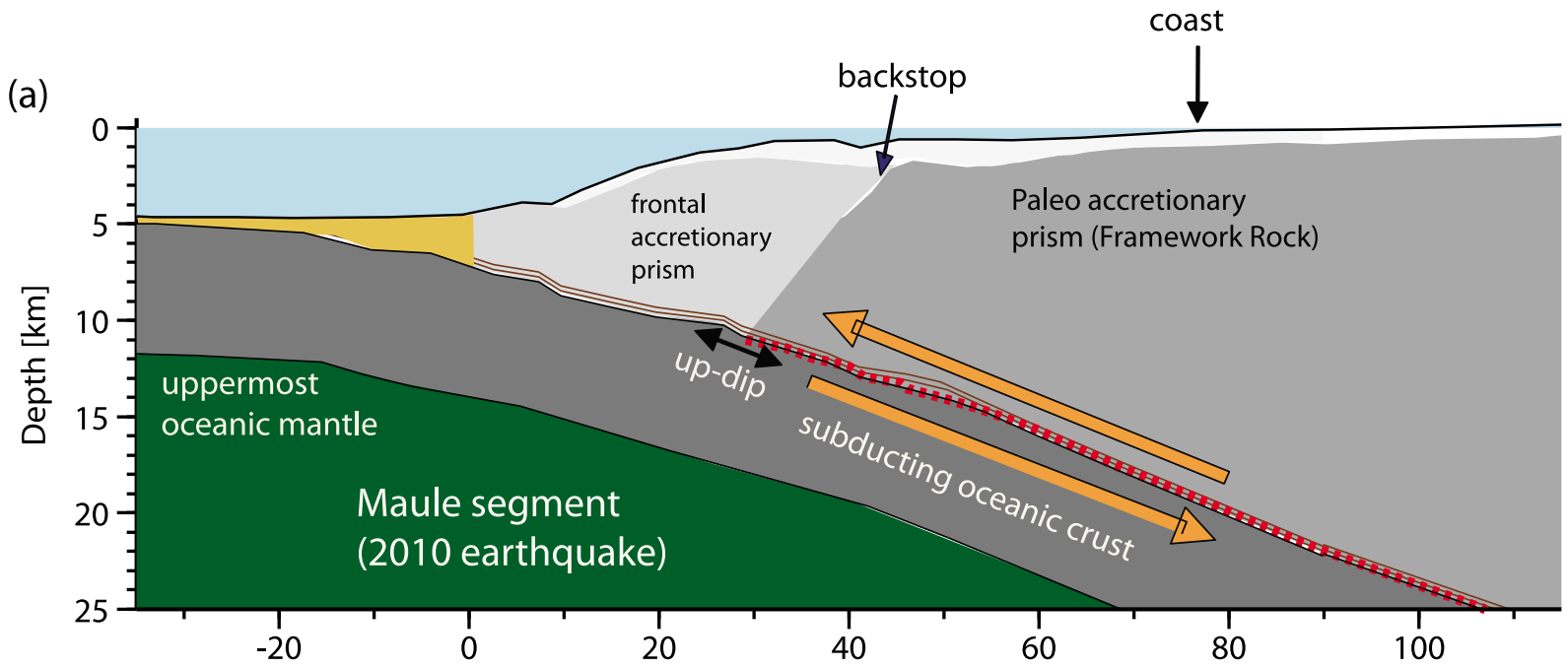

Distance from the deformation front $[\mathrm{km}]$

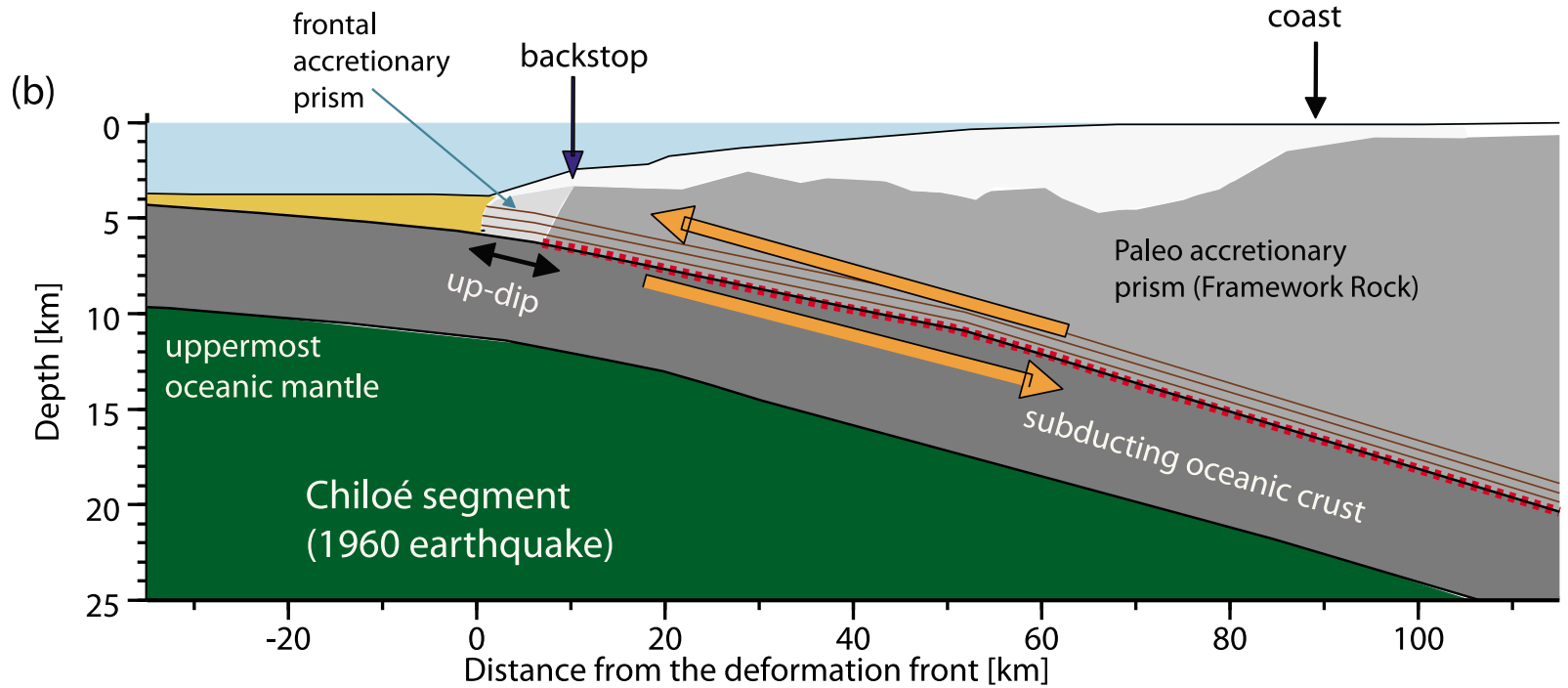

Figure 14. Sketch based on the seismic velocity models shown in Figures 8-12. Locations of the updip limits for the coseismic rupture area of the (a) 2010 and (b) 1960 earthquakes are shown. The updip limit of the 2010 Maule earthquake is located 30-40 km landward of the deformation front and 40-50 km seaward of the coast, while the updip limit of the 1960 Valdivia earthquake is located 5-10 km landward of the deformation and 70-80 km from the coast line. The updip limit of 1960 earthquake extends about $30 \mathrm{~km}$ further seaward than the 2010 earthquake. Thus, we anticipated that the Maule earthquake-fault slip did not extend up to the trench which might explains the limited scope of the tsunami compared with the trans-Pacific 1960 earthquake.

larger is the tsunami amplitude. The water volume above the offshore part of the seismogenic zone along the Chiloé segment is substantially larger than above the offshore part of the seismogenic zone along the Maule segment (Figure 14). A rough estimate of the sea area and volume of water overlying the seismogenic zone can be calculated: (1) using the information shown in Figure 14, (2) extrapolating the updip limit position along strike for the Chiloé and Maule segments, and (3) using the length of earthquake rupture along strike of the 1960 and 2010 earthquakes, which are $\sim 950 \mathrm{~km}$ and $\sim 550 \mathrm{~km}$, respectively. The volume of water overlying the offshore part of the seismogenic zone is approximately $340,000 \mathrm{~km}^{3}$ and $15,000 \mathrm{~km}^{3}$ for the 1960 and 2010 earthquakes, respectively. That is, the amount of water overlying the seafloor in the seismogenic zone of the 1960 earthquake is about 20 times larger than the 2010 earthquake. This could explain why the tsunami wave was excited efficiently along the 1960 earthquake rupture area, causing a transoceanic tsunami. In sharp contrast, the regional 2010 tsunami affected only the SC Chile coast and the Juan Fernández Islands. 


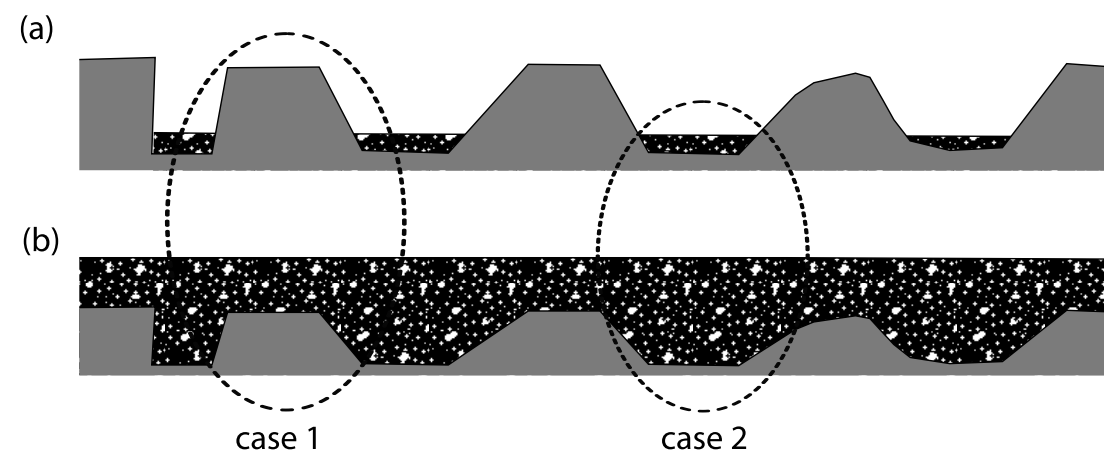

Figure 15. Subduction interface with a (a) thin and (b) thick subduction channel cover. A thick subduction channel is expected to lower the coupling degree above a high relief zone (case 1), while a thick subduction channel is expected to increase it between high relief regions (case 2). These processes smooth the plate interface contact and favor earthquake rupture propagation.

\subsubsection{Implications of a Thick Subduction Channel for Seismicity}

[59] As was demonstrated above, the Chilean subduction zone frequently generates giant earthquakes, with fault area dimensions reaching hundreds of kilometers, and destructive tsunamis. The dynamics of the seismogenic zone is controlled by heterogeneities of high shear stress across the subduction interface. These seismic heterogeneities have been recognized as asperities and barriers to earthquake rupture that control the seismic moment release and the rupture area size [Beck and Ruff, 1984; Das and Watts, 2009]. Strongly coupled regions, called asperities, slip during the earthquake. Once the yield stress along these asperities is exceeded by the accumulated interseismic stress, the asperity concentrates the coseismic moment release and slip during the earthquake. The rupture front can start in either a weak or strong couple region, but most break the dominant asperity. The rupture front stops either at a major seismic barrier or in a weak region that has previously slipped and therefore is not highly stressed [Ruff, 1989].

[60] The size of the rupture area and hence the earthquake magnitude depend on where the earthquake rupture front starts and stops. The efficiency of lateral earthquake rupture propagation depends on the distribution of asperities and barriers along the subduction interface. For example, a rough oceanic topography translates into highly heterogeneous strength distribution and, between regions of high relief, would behave aseismic due to its weak coupling (Figure 15a), which will result in small earthquake generation [Ruff, 1989]. In contrast, a thick subduction channel (Figure 15b) will allow a smoother strength distribution along the plate interface, resulting in a highly homogeneous strength distribution [Ruff, 1989; Scholl et al., 2007]. It is expected that a thick subduction channel would reduce coupling above topographic heterogeneities (case 1, Figure 15) and increase plate coupling between high topographies (case 2, Figure 15). Thus, these two process together will favor a homogeneous plate contact and consequently earthquake rupture propagation.

[61] It has been noted that large-magnitude earthquakes $\left(M_{w}>8.5\right)$ nucleated along accretionary margins, such as southern Chile $\left(1960, M_{w}=9.5\right)$, eastern Alaska $\left(1964, M_{w}=\right.$ 9.2), Sumatra (2004, $M_{w}=9.1$ ), west-central Aleutian (1965, $\left.M_{w}=8.7\right)$, central Aleutian $\left(1986, M_{w}=8.7\right)$, Sumatra (2005
$M_{w}=8.6$ ), and Nankai (historic $1707, M_{w}=8.5$ ). The subduction channel along these subduction zones is typically $\geq 1.5 \mathrm{~km}$ and is axially continuous for more than $800 \mathrm{~km}$ [Scholl et al., 2007]. Ridges and high relief entering the subduction zone can terminate rupturing, unless these high oceanic features are covered by a thick sedimetary layer (subduction channel). One excellent example to study the interplay between the subduction channel and subducted high oceanic features is the 1960 Valdivia earthquake. The rupture area of this giant earthquake $\left(M_{w}=9.5\right)$ is located between the Peninsula de Arauco and a few kilometers north of the CTJ [Barrientos and Ward, 1990; Moreno et al., 2009], which is fairly coincident with the Chiloé segment characterized by a thick subduction channel. The 1960 event ruptured across six major fractures zones and it did stop near Mocha FZ in the north and at the CTJ in the south. Thus, the high relief of the subducting Mocha FZ and the Chile Rise at the CTJ behave as barriers during the rupture. In contrast, a thick subduction channel along the rupture zone may provide enough smoothness for long rupture propagation across the fracture zones involved [Scherwath et al., 2009]. We therefore conclude that lateral earthquake rupture propagation is dramatically controlled by the size of the smoothed area along the subduction interface. Outcropping oceanic basement highs are the most obvious candidates for seismic barriers arresting lateral rupture propagation. Consequently, the rupture process of the latest 2010 earthquake $\left(M_{w}=8.8\right)$ is fairly coincident with the subduction of the JFR in the north and Mocha FZ in the south (Figure 2b). The coseismic rupture zone is confined between $\sim 34^{\circ} \mathrm{S}$ and $\sim 38^{\circ} \mathrm{S}$ according to preliminary slip fault models [http://www.tectonics.caltech.edu/slip_history/ 2010_chile/prelim-gps.html; Moreno et al., 2010] and coastal land-level changes observations [Farías et al., 2010], whereas the postseismic rupture zone is confined between the JFR and Mocha FZ according to the aftershock distribution [http://neic. usgs.gov]. Thus, these high oceanic features have behaved as strong barriers for lateral rupture propagation.

\section{Summary}

[62] The southern central Chile margin $\left(33^{\circ}-45^{\circ} \mathrm{S}\right)$ can be characterized by two main segments that present differences 
in their frontal accretionary prism size and their subduction channel thickness. The northern segment (Maule segment) confined between the Juan Fernández Ridge and the Mocha block $\left(33^{\circ}-\sim 39^{\circ} \mathrm{S}\right)$ is characterized by an FAP $20-40 \mathrm{~km}$ wide and a subduction channel typically thinner than $1 \mathrm{~km}$. The southern segment (Chiloé segment) is situated between the Mocha block and the Chile triple junction $\left(\sim 39^{\circ}-45^{\circ} \mathrm{S}\right)$ and is characterized by an extremely small FAP $(<10 \mathrm{~km}$ wide) and a thick subduction channel $(\sim 1.5 \mathrm{~km})$.

[63] Seismic evidence revealed that sediment accretion is more effective in the Maule segment, which is a region characterized by the subduction of the Nazca plate with age ranging from 30 to $38 \mathrm{Ma}$. In contrast, efficient sediment subduction occurs where the young Nazca plate (5-25 Ma) subducts beneath South America along the Chiloé segment.

[64] The location of the updip limit of the 2010 and 1960 megathrust earthquakes is revealed in terms of the backstop imaged by seismic wide-angle velocity models. The updip limit of the 2010 Maule earthquake is located $30-40 \mathrm{~km}$ landward of the deformation front and $\sim 50 \mathrm{~km}$ seaward of the coast, while the updip limit of the 1960 Valdivia earthquake is located near the trench and $80-90 \mathrm{~km}$ from the coast. The seismogenic zone of the 1960 extends further seaward for more than $25 \mathrm{~km}$ than the seismogenic zone of the 2010 earthquake and it reaches deep water (3000-4500 m). The expected volume of water overlying the seismogenic zone along the Chiloé segment is about 20 times larger than along the Maule segment. This might explain the generation of the 1960 megatsunami affecting most of the Pacific coast in contrast to the regional 2010 tsunami, which affected "only" the southern central Chile coast and the Juan Fernández Islands.

[65] The thick subduction channel along the Chiloé segment correlates with the rupture area of the great 1960 Chile earthquake $\left(M_{w}=9.5\right)$, which likely ruptured through an area with smoothed plate coupling and ceased in the area of a thin subduction channel near the Chile triple junction [Scherwath et al., 2009].

[66] Acknowledgments. Eduardo Contreras-Reyes acknowledges the support of the Chilean National Science Foundation (FONDECYT) project 11090009. Seismic refraction and wide-angle data used in the study were acquired during the cruise SO181 of the German R/V SONNE. Sea-going effort were sponsored by the German government (BMBF grant 03G0181A). We thank Daniel Melnick, Dave Scholl, the Associate Editor, and editor Todd Ehlers for careful reviews of the manuscript. We thank Dave Rahn for comments on the English. Fruitful discussions with Nathan Bangs, Roland von Huene, and Daniel Carrizo are greatly appreciated.

\section{References}

Angermann, D., J. Klotz, and C. Reigber (1999), Spacegeodetic estimation of the Nazca-South America Euler vector, Earth Planet. Sci. Lett., 171(3), 329-334.

Bangs, N. L., and S. C. Cande (1997), Episodic development of a convergent margin inferred from structures and processes along the southern Chile margin, Tectonics, 16(3), 489-503.

Bangs, N., and G. Westbrook (1991), Seismic modeling of the decollement zone at the base of the Barbados Ridge Accretionary Complex, J. Geophys. Res., 96(B3), 3853-3866.

Bangs, N. L. B., G. F. Moore, S. P. S. Gulick, E. M. Pangborn, H. J. Tobin, S. Kuramoto, and A. Taira (2009), Broad, weak regions of the Nankai Megathrust and implications for shallow coseismic slip, Earth Planet. Sci. Lett., 284(1), 44-49, doi:10.1016/ j.eps1.2009.04.026

Barrientos, S. E., and S. N. Ward (1990), The 1960 Chile earthquake: Inversion for slip distribution from surface deformation, Geophys. J. Int., 103, 589-598.

Beck, S., and L. Ruff (1984), The rupture process of the great 1979 Colombia earthquake: Evidence for the asperity model, J. Geophys. Res., 89(B11), 9281-9291.

Behrmann, J. H., and A. Kopf (2001), Balance of tectonically accreted and subducted sediment at the Chile Triple Junction, Int. J. Earth Sci., 90 , 753-768.

Behrmann, J. S., S. D. Leslie, S. C. Cande, and ODP Leg 141 Scientific Party (1994), Tectonics and geology of spreading ridge subduction at the Chile Triple Junction: A synthesis of results from Leg 141 of the Ocean Drilling Program, Geol. Rundsch., 83, 832-852.

Bourgois, J., H. Martin, Y. Lagabrielle, J. Le Moigne, and J. Frutos Jara (1996), Subduction erosion related to spreading-ridge subduction: Taitao Peninsula (Chile margin triple junction area), Geology, 24, 723-726.

Bourgois, J., C. Guivel, Y. Lagabrielle, T. Calmus, J. Boulague, and V. Daux (2000), Glacial-interglacial trench supply variation, spreading-ridge subduction, and feedback controls on the Andean margin development at the Chile triple junction area $\left(45^{\circ}-48^{\circ} \mathrm{S}\right)$, J. Geophys. Res., 105(B4), 8355-8386.
Byrne, D. E., D. M. Davis, and L. R. Sykes (1988), Loci and maximum size of thrust earthquakes and the mechanics of the shallow region of subduction zones, Tectonics, 7(4), 833-857.

Byrne, D. E., W. Wang, and D. M. Davis (1993), Mechanical role of backstops in the growth of forearcs, Tectonics, 12(1), 123-144.

Calahorrano, A., V. Sallares, J.-Y. Collota, F. Sagea, and C. R. Ranero (2008), Nonlinear variations of the physical properties along the southern Ecuador subduction channel: Results from depth-migrated seismic data, Earth Planet. Sci. Lett., 267(3-4), 453-467.

Cande, S. C., and R. B. Leslie (1986), Late Cenozoic tectonics of the southern Chile Trench, J. Geophys. Res., 91, 471-496.

Clift, P., and P. Vannucchi (2004), Controls on tectonic accretion versus erosion in subduction zones: Implications for the origin and recycling of the continental crust, Rev. Geophys., 42, RG2001, doi:10.1029/ 2003 RG000127.

Cloos, M., and R. L. Shreve (1988), Subductionchannel model of prism accretion, melange formation, sediment subduction, and subduction erosion at convergent plate margins: 2 . Implications and discussion, Pure Appl. Geophys., 128(3-4), 501-545.

Collot, J.-Y., W. Agudelo, A. Ribodetti, and B. Marcaillou (2008), Origin of a crustal splay fault and its relation to the seismogenic zone and underplating at the erosional north Ecuador-south Colombia oceanic margin, J. Geophys. Res., 113, B12102, doi:10.1029/2008JB005691.

Contardo, X., J. Cembrano, A. Jensen, and J. DíazNaveas (2008), Tectono-sedimentary evolution of marine slope basins in the Chilean forearc $\left(33^{\circ} 30^{\prime}-\right.$ $\left.36^{\circ} 50^{\prime} \mathrm{S}\right)$ : Insights into their link with the subduction process, Tectonophysics, 459(1-4), 206-218.

Contreras-Reyes, E., and A. Osses (2010), Lithospheric flexure modeling seaward of the Chile trench: Implications for oceanic plate weakening in the Trench Outer Rise region, Geophys. J. Int., 182(1), 97-112, doi:10.1111/j.1365-246X.2010.04629.x.

Contreras-Reyes, E., I. Grevemeyer, E. R. Flueh, M. Scherwath, and M. Heesemann (2007), Alteration of the subducting oceanic lithosphere at the southern central Chile trench-outer rise, Geochem. Geophys. Geosyst., 8, Q07003, doi:10.1029/2007GC001632.

Contreras-Reyes, E., I. Grevemeyer, E. R. Flueh, and C. Reichert (2008), Upper lithospheric structure of the subduction zone offshore southern Arauco Peninsula, Chile at $\sim 38^{\circ} \mathrm{S}, J$. Geophys. Res., 113, B07303, doi:10.1029/2007JB005569.

Das, S., and A. B. Watts (2009), Effect of subducting seafloor topography on the rupture characteristics of great subduction zone earthquakes, in Subduction Zone Geodynamics, edited by S. Lallemand and F. Funiceillo, pp. 103-118, Springer-Verlag, Berlin/Heidelberg.

DeMets, C., R. G. Gordon, D. F. Argus, and S. Stein (1994), Effect of recent revisions to the geomagnetic reversal time scale on estimates of current plate motions, Geophys. Res. Lett., 21(20), 2191-2194, doi:10.1029/94GL02118.

Diaz-Naveas, J. L. (1999), Sediment subduction and accretion at the Chilean convergent margin between $35^{\circ}$ and $40^{\circ} \mathrm{S}$, Ph.D. dissertation, ChristianAlbrecht-Univ., Kiel, Germany.

Encinas, A., K. L. Finger, S. N. Nielsen, A. Lavenu, L. A. Buatois, D. E. Peterson, and J. P. Le Roux (2008), Rapid and major coastal subsidence during the late Miocene in south-central Chile, J. South Am. Earth Sci., 25(2), 157-175.

Farías, M., G. Vargas, A. Tassara, S. Carretier, S. Baize, D. Melnick, and K. Bataille (2010), Land-level changes produced by the $M_{w} 8.82010$ Chilean earthquake, Science, 916, doi:10.1126/science.1192094.

Flueh, E. R., and I. Grevemeyer (Eds.) (2005), TIPTEQ SONNE Cruise SO-181: From the incoming plate to mega thrust earthquakes, Rep. 102, IFM-GEOMAR, Kiel, Germany.

Flueh, E. R., N. Vidal, C. R. Ranero, A. Hojka, R. von Huene, J. Bialas, K. Hinz, D. Cordoba, J. J. Danobeitia, and C. Zelt (1998), Seismic investigations of the continental margin off- and onshore Valparaiso, Chile, Tectonophysics, 288, 251-263.

Flueh, E. R., H. Koop, and B. Schreckenberger (Eds.) (2002), Subduction processes off Chile, cruise report, IFM-GEOMAR, Kiel, Germany.

Gerdom, M., A. M. Trehub, E. R. Flueh, and D. Klaeschen (2000), The continental margin off 
Oregon from seismic Investigations, Tectonophysics, 329, 79-97.

Glodny, J., et al. (2006), Long-term geological evolution and mass-flow balance of the South-Central Andes, in Frontiers in Earth Science, vol. 3, The Andes: Active Subduction Orogeny, edited by O. Oncken et al.,pp. 401-428, Springer, Berlin.

Gonzalez, E. (1989), Hydrocarbon resources in the coastal zone of Chile, in Geology of the Andes and Its Relation to Hydrocarbon and Mineral Resources, edited by G. Ericksen et al., pp. 383-404, CircumPac. Counc. for Energy and Miner. Resour., Houston, Tex.

Grevemeyer, I., J. L. Diaz-Naveas, C. R. Ranero, H. Villinger, and Ocean Drilling Program Leg 202 Scientific Party (2003), Heat flow over the descending Nazca plate in central Chile, $32^{\circ} \mathrm{S}$ to $41^{\circ} \mathrm{S}$ : Observations from ODP Leg 202 and the occurrence of natural gas hydrates, Earth Planet. Sci. Lett., 213, 285-298, doi:10.1016/S0012-821X(03)00303-0.

Haberland, C., A. Rietbrock, D. Lange, K. Bataille, and S. Hofmann (2006), Interaction between forearc and oceanic plate at the south-central Chilean margin as seen in local seismic data, Geophys. Res. Lett., 33, L23302, doi:10.1029/2006GL028189.

Haberland, C., A. Rietbrock, D. Lange, K. Bataille, and T. Dahm (2009), Structure of the seismogenic zone of the southcentral Chilean margin revealed by local earthquake traveltime tomography, J. Geophys. Res., 114, B01317, doi:10.1029/2008JB005802.

Herron, E. M., S. C. Cande, and B. R. Hall (1981), An active spreading center collides with a subduction zone: A geophysical survey of the Chile margin triple junction, Geol. Soc. Am. Mem., 154, 683-701.

Herve, F. E., F. Munizaga, M. A. Parada, M. Brook, R. Pankhurst, N. Spelling, and R. Drake (1988), Ganitoids of the coast range of central Chile: Geochronology and geologic setting, S. Am. Earth Sci. J., 1, 185-194.

Herve, M. (1976), Estudio geologico de la falla LiquineReloncavi en el area de Liquine: antecedentes de un movimiento transcurrente (Provincia de Valdivia), Actas Congr. Geol. Chil., 1, B39-B56.

Jarrard, R. D. (1986), Relations among subduction parameters, Rev. Geophys., 24(2), 217-284.

Klingelhoefer, F., M.-A. Gutscher, S. Ladage, J.-X. Dessa, D. Graindorge, D. Franke, C. André, H. Permana, T. Yudistira, and A. Chauhan (2010), Limits of the seismogenic zone in the epicentral region of the 26 December 2004 great SumatraAndaman earthquake: Results from seismic refraction and wide-angle reflection surveys and thermal modeling, J. Geophys. Res., 115, B01304, doi:10.1029/2009JB006569.

Kopp, H., E. R. Flueh, C. Papenberg, and D. Klaeschen (2004), Seismic investigations of the O'Higgins Seamount Group and Juan Fernandez Ridge: A seismic ridge emplacement and lithosphere hydration, Tectonics, 23, TC2009, doi:10.1029/2003TC001590.

Korenaga, J., W. S. Holbrook, G. M. Kent, P. B. Kelemen, R. S. Detrick, H.-C. Larsen, J. R. Hopper, and T. Dahl-Jensen (2000), Crustal structure of the southeast Greenland margin from joint refraction and reflection seismic tomography, J. Geophys. Res., 105(B9), 21,591-21,614.

Kukowski, N., and O. Oncken (2006), Subduction erosion: The "normal" mode of forearc material transfer along the Chilean margin?, in Frontiers in Earth Sciences, vol. 3, The Andes: Active Subduction Orogeny, edited by O. Oncken et al., pp. 217-236, Springer, Berlin.

Lange, D., A. Rietbrock, C. Haberland, K. Bataille, T. Dahm, F. Tilmann, and E. R. Flüh (2007), Seismicity and geometry of the south Chilean subduction zone $\left(41.5^{\circ} \mathrm{S}-43.5^{\circ} \mathrm{S}\right)$ : Implications for controlling parameters, Geophys. Res. Lett., 34, L06311, doi:10.1029/2006GL029190.

Laursen, J., D. W. Scholl, and R. von Huene (2002), Neotectonic deformation of the central Chile margin: Deepwater forearc basin formation in response to hot spot ridge and seamount subduction, Tectonics, 21(5), 1038, doi:10.1029/2001TC901023.
Melnick, D., and H. Echtler (2006), Inversion of forearc basins in south-central Chile caused by rapid glacial age trench fill, Geology, 34(9), 709-712.

Mordojovich, C. (1974), Geology of a part of the Pacific margin of Chile, in The Geology of Continental Margins, edited by C. A. Burk and C. L. Drake, pp. 591-598, Springer, New York.

Mordojovich, C. (1981), Sedimentary basins of the Chilean Pacific offshore, AAPG Stud. Geol., 12 , 732-749.

Moreno, M. S., J. Bolte, J. Klotz, and D. Melnick (2009), Impact of megathrust geometry on inversion of coseismic slip from geodetic data: Application to the 1960 Chile earthquake, Geophys. Res. Lett., 36 , L16310, doi:10.1029/2009GL039276.

Moreno, M., M. Rosenau, and O. Oncken (2010), Maule earthquake slip correlates with pre-seismic locking of Andean subduction zone, Nature, 467, 198-202, doi:10.1038/nature09349.

Mueller, R. D., W. R. Roest, J.-Y. Royer, L. M. Gahagan, and J. G. Sclater (1997), Digital isochrons of the world's ocean floor, J. Geophys. Res., 102(B2), 3211-3214

Nakanishi, A., N. Takahashi, J.-O. Park, S. Miura, S. Kodaira, Y. Kaneda, N. Hirata, T. Iwasaki, and M. Nakamura (2002), Crustal structure across the coseismic rupture zone of the 1944 Tonankai earthquake, the central Nankai Trough seismogenic zone, J. Geophys. Res., 107(B1), 2007, doi:10.1029 2001JB000424.

Okada, Y. (1992), Internal deformation due to shear and tensile faults in a half-space, Bull. Seismol. Soc. Am., 82(2), 1018-1040.

Oleskevich, D., R. Hyndman, and K. Wang (1999), The updip and downdip limits to great subduction earthquakes: Thermal and structural models of Cascadia South Alaska, SW Japan, and Chile, J. Geophys. Res., 104(B7), 14,965-14,991.

Patzwahl, R., J. Mechie, A. Schulze, and P. Giese (1999), Two-dimensional velocity models of the Nazca plate subduction zone between $19.5^{\circ} \mathrm{S}$ and $25^{\circ} \mathrm{S}$ from wide-angle seismic measurements during the CINCA95 project, J. Geophys. Res., 104(B4), 7293-7317.

Polonia, A., L. Torelli, G. Brancolini, and M.-F. Loreto (2007), Tectonic accretion versus erosion along the southern Chile trench: Oblique subduction and margin segmentation, Tectonics, 26, TC3005, doi:10.1029/2006TC001983.

Rabassa, J., and C. M. Clapperton (1990), Quaternary glaciations of the southern Andes, Quat. Sci. Rev., 9, 153-174.

Ranero, C. R., R. von Huene, W. Weinrebe, and C. Reichert (2006), Tectonic processes along the Chile Convergent Margin, in Frontiers in Earth Sciences, vol. 3, The Andes: Active Subduction Orogeny, edited by O. Oncken et al., pp. 91-121, Springer, Berlin.

Rauch, K. (2005), Cyclicity of Peru-Chile trench sediments between $36^{\circ}$ and $38^{\circ} \mathrm{S}$ : A footprint of paleoclimatic variations?, Geophys. Res. Lett., 32 L08302, doi:10.1029/2004GL022196.

Reichert, C., B. Schreckenberger, and SPOC Team (2002), Fahrtbericht SONNE-Fahrt SO-161 Leg 2 and 3 SPOC, Subduktionsprozesse vor chileBMBF-Forschungsvorhaben 03G0161A- Valparaiso 16.10.2001-Valparaiso 29.11.2001, Bundesanstal für Geowissenschaften und Rohstoffe, Hannover, Germany.

Ruff, L. J. (1989), Do trench sediments affect great earthquake occurrence in subduction zones?, Pure Appl. Geophys., 129(1-2), 263-282.

Sage, F., J.-Y. Collot, and C. R. Ranero (2006), Interplate patchiness and subduction-erosion mechanisms: Evidence from depth-migrated seismic images at the central Ecuador convergent margin, Geology, 34(12), 997-1000.

Sallares, V., and C. R. Ranero (2005), Structure and tectonics of the erosional convergent margin off Antofagasta, north Chile $\left(23^{\circ} 30^{\prime} \mathrm{S}\right), J$. Geophys. Res., 110, B06101, doi:10.1029/2004JB003418.
Scherwath, M., E. R. Flueh, I. Grevemeyer, F. Tilmann, E. Contreras-Reyes, and R. W. Weinrebe (2006), Investigating subduction zone processes in Chile, Eos Trans. AGU, 87(27), 265-272, doi:10.1029/ 2006EO270001.

Scherwath, M., E. Contreras-Reyes, E. R. Flueh, I. Grevemeyer, A. Krabbenhoeft, C. Papenberg, C. J. Petersen, and R. W. Weinrebe (2009), Deep lithospheric structures along the southern central Chile margin from wide-angle $\mathrm{P}$-wave modelling, Geophys. J. Int., 179(1), 579-600.

Scholl, D. W., and R. von Huene (2007), Crustal recycling at modern subduction zones applied to the past: Issues of growth and preservation of continental basement, mantle geochemistry, and supercontinent reconstruction, in The 4D Framework of Continental Crust, edited by R. D. Hatcher Jr. et al., Mem. Geol. Soc. Am., 200, 9-32.

Scholl, D. W., S. H. Kirby, K. M. Keranen, R. E. Wells, R. J. Blakely, F. Michael, and R. von Huene (2007), Megathrust slip and the care and feeding of the subduction channel through which the seismogenic zone runs, Eos Trans. AGU, 88(52), Fall Meet. Suppl., Abstract T51E-06.

Scholz, C. H. (2002), The Mechanics of Earthquakes and Faulting, 2nd ed., Cambridge Univ. Press, Cambridge, U. K.

Seifert, W., M. Rosenau, and H. Echtler (2005), Crystallization depths of granitoids of South Centra Chile estimated by AL-in-hornblende geobarometry: Implications for mass transfer processes along the active continental margin, Neues Jahrb. Geol. Palaeontol. Abh., 236, 115-127.

Somoza, R. (1998), Updated Nazca (Farallon)-South America relative motions during the last $40 \mathrm{Myr}$ : Implications for mountain building in the central Andean region, J. S. Am. Earth Sci., 11, 211-215.

Tebbens, S. F., S. C. Cande, L. Kovacs, J. C. Parra, J. L. LaBrecque, and H. Vergara (1997), The Chile ridge: A tectonic framework, J. Geophys. Res., 102(B6), 12,035-12,060, doi:10.1029/96JB02581.

Thornburg, T. M., and D. M. Kulm (1987), Sedimentation in the Chile Trench: Depositional morphologies, lithofacies, and stratigraphy, Geol. Soc. Am. Bull., 98, 33-52.

Thornburg, T. M., D. M. Kulm, and D. M. Hussong (1990), Submarine-fan development in the southern Chile trench: A dynamic interplay of tectonics and sedimentation, Geol. Soc. Am. Bull., 102, 1658-1680.

Tichelaar, B., and L. Ruff (1993), Depth of seismic coupling along subduction zones, J. Geophys. Res., 98(B2), 2017-2037.

Tilmann, F. J., T. J. Craig, I. Grevemeyer, B. Suwargadi, H. Kopp, and E. Flueh (2010), The updip seismic/ aseismic transition of the Sumatra megathrust illuminated by aftershocks of the 2004 Aceh-Andaman and 2005 Nias events, Geophys. J. Int., 181(3), 1261-1274.

van Avendonk, H. J. A., A. J. Harding, and J. A. Orcutt (1998), A two-dimensional tomographic study of the Clipperton transform fault, J. Geophys. Res. 103, 17,885-17,899.

Völker, D., M. Wiedicke, S. Ladage, C. Gaedicke, C. Reichert, K. Rauch, W. Kramer, and C. Heubeck (2006), Latitudinal variation in sedimentary processes in the Peru-Chile Trench off central Chile, in Frontiers in Earth Sciences, vol. 3, The Andes: Active Subduction Orogeny, edited by O. Oncken et al., pp. 193-216, Springer, Berlin.

von Huene, R., and C. R. Ranero (2003), Subduction erosion and basal friction along the sediment-starved convergent margin off Antofagasta, Chile, J. Geophys. Res., 108(B2), 2079, doi:10.1029/2001JB001569.

von Huene, R., and D. W. Scholl (1991), Observations at convergent margins concerning sediment subduction, subduction erosion, and the growth of continental crust, Rev. Geophys., 29(3), 279-316, doi:10.1029/90JB00230.

von Huene, R., J. Corvalán, E. R. Flueh, K. Hinz, J. Korstgard, C. R. Ranero, W. Weinrebe, and the CONDOR Scientists (1997), Tectonic Control of the subducting Juan Fernández Ridge on the Andean 
margin near Valparaíso, Chile, Tectonics, 16(3), 474-488.

von Huene, R., C. R. Ranero, and D. W. Scholl (2009), Convergent margin structure in high-quality geophysical images and current kinematic and dynamic models, in Subduction Zone Geodynamics, edited by S. Lallemand and F. Funiciello, vol. 137, pp. 137-157, Springer, Berlin.

Wang, K., and Y. Hu (2006), Accretionary prisms in subduction earthquake cycles: The theory of dynamic Coulomb wedge, J. Geophys. Res., 111, B06410, doi:10.1029/2005JB004094.

Watts, A. B. (2001), Isostasy and Flexure of the Lithosphere, 458 pp., Cambridge Univ. Press, New York.
Wells, R. E., R. J. Blakely, Y. Sugiyama, D. W. Scholl, and P. A. Dinterman (2003), Basin-centered asperities in great subduction zone earthquakes: A link between slip, subsidence, and subduction erosion?, J. Geophys. Res., 108(B10), 2507, doi:10.1029/ 2002JB002072.

Yáñez, G., C. R. Ranero, and J. Díaz (2001), Magnetic Anomaly interpretation across the southern central Andes $\left(32^{\circ}-34^{\circ} \mathrm{S}\right)$ : The role of the Juan Fernández Ridge in the late Tertiary evolution of the margin, J.Geophys. Res., 106 (B4), 6325-6345.

Zelt, C. A. (1999), Modelling strategies and model assessment for wide-angle seismic traveltime data, Geophys. J. Int., 139, 183-204, doi:10.1046/ j.1365-246X.1999.00934.x.
Zelt, C. A., and R. B. Smith (1992), Seismic traveltime inversion for 2-D crustal velocity structure, Geophys. J. Int., 108, 16-34.

E. Contreras-Reyes, Departamento de Geofísica, Facultad de Ciencias de Físicas y Matemáticas, Universidad de Chile, 8370448 Santiago, Chile. (econtreras@dgf.uchile.cl)

E. R. Flueh and I. Grevemeyer, IFM-GEOMAR, Leibniz-Institute für Meereswissenchaften an Universität Kiel, Wischhofstr. 1-3, D-24148 Kiel, Germany. 